\title{
The narrative constitution of identity: A relational and network approach
}

\author{
MARGARET R. SOMERS \\ University of Michigan
}

This article argues for reconfiguring the study of identity formation through the concept of narrative. It is motivated by two recent but seemingly unrelated developments in social theory and society. One is the emergence of a wide-spread "identity politics" and a concomitant scholarly focus on the "social construction of identity." The other is the reconfigured approach to the concept of narrative that researchers from many disciplines have been formulating in recent years. Both are important developments not to be overlooked by social scientists and social theorists; both, however, have problems and limitations as they now stand. I argue in this article that the limitations of each potentially can be overcome by bringing the two thematics together. The key concept I propose to achieve this reconfiguration is that of narrative identity.

Studies of identity formation have made major contributions to our understanding of social agency. A recurring problem, however, has been a perhaps inadvertent tendency to conflate identities with what can often slide into fixed "essentialist" (pre-political) singular categories, such as those of race, sex, or gender - a direction that has characterized a number of feminist theories in their efforts to restore the previously marginalized female other. ${ }^{1}$ Anthropological studies of different cultures have been been used to avoid this danger. ${ }^{2}$ But, law professor Patricia Williams reminds us that we do not have to resort to cultural others to recognize the false certainties imposed by categorical approaches to identity:

\footnotetext{
While being black has been the powerful social attribution in my life, it is only one of a number of governing narratives or presiding fictions by which I am constantly reconfiguring myself in the world. Gender is another, along with ecology, pacifism, my peculiar brand of colloquial English, and Roxbury, Massachusetts. The complexity of role identification, the politics of sexuality, the inflections of professionalized discourse - all describe and impose
} 
boundary in my life, even as they confound one another in unfolding spirals of confrontation, deflection, and dream....

One way to avoid the hazards of rigidifying aspects of identity into a misleading categorical entity is to incorporate into the core conception of identity the categorically destabilizing dimensions of time, space, and relationality. We can do this by bringing to the study of identity formation the epistemological and ontological challenges of relational and network analysis. It is this effort to historicize our understanding of identity that motivates my attempt to combine studies of identity with a conceptual narrativity.

The study of narrative, on the face of it, has its own serious limitations. Most prominently, narrative analysis is not something easily assimilated into the social-science research agenda. With its long association with the humanities and the "story-telling" methods of historians, the concept of narrative, after all, has long fulfilled the role of social science's "epistemological other" - a mode of representation that was, apparently, discursive, rather than quantitative; non-explanatory, rather than conditionally propositional; and non-theoretical, rather than one of the theoretically-driven social sciences. ${ }^{4}$ In the 1960 s and 1970 s, however, social science history had emerged as a serious contender to the traditional historians' narrative approach and these decades were notable for the degree to which historians debated and increasingly scorned the value of narrative as a representational form. ${ }^{5} \mathrm{At}$ the same time, however, disciplines other than history (political philosophers, psychologists, legal theorists, feminist theorists, social workers, organizational theorists, anthropologists, and medical sociologists) were quietly appropriating and reconceptualizing the narrative concept. ${ }^{6}$ In so doing, they were reconfiguring in radical ways the narrative concept. While the older interpretation of narrative was limited to that of a representational form, the new approaches define narrative and narrativity as concepts of social epistemology and social ontology. These concepts posit that it is through narrativity that we come to know, understand, and make sense of the social world, and it is through narratives and narrativity that we constitute our social identities. They argue that it matters not whether we are social scientists or subjects of historical research, but that all of us come to be who we are (however ephemeral, multiple, and changing) by being located or locating ourselves (usually unconsciously) in social narratives rarely of our own making. ${ }^{7}$ Social theorists and sociologists need to become cognizant of these new formulations of narrative analysis. 
The attraction of linking the study of identity formation to narrative analysis should now be clearer. Engaging with this aspect of narrative studies clearly should be on the agenda for sociological studies of action and agency. After all, if research results are correct, then everything we know, from making families, to coping with illness, to carrying out strikes and revolutions is at least in part a result of numerous crosscutting relational story-lines in which social actors find or locate themselves. ${ }^{8}$ By focusing attention on the new ontological dimension of narrative studies rather than on the traditional rendering of narrative as limited to a method or form of representation, we have the opportunity to engage with historically and empirically based research into social action and social agency that is at once temporal, relational, and cultural, as well as institutional, material, and macro-structural. An energetic engagement with this new ontological narrativity provides an opportunity to infuse the study of identity formation with a relational and historical approach that avoids categorical rigidities by emphasizing the embeddedness of identity in overlapping networks of relations that shift over time and space. My larger hope is that bringing together narrative and identity can bring a new perspective to some of the seemingly intractable problems contained in social theories of action. In the next section, I explore the new sociology and politics of identity; in the succeeding section, I discuss in more detail the reframed concept of narrative; in the third section, I position the concepts of narrative identity and relational setting as conceptual links between the reframed approach to narrative and some of the enduring conundrums in the sociology of action; and I end by considering some of the research implications of a conceptual narrativity.

\section{The politics of identity: From universality to category}

In recent years, social theory has been confronted with a set of extraordinary challenges - ones that have arisen in part from external political and social transformations and in part from theoretical attempts to make sense of those social developments. The political and social elements are best represented by such factors as the "failure" of western working classes to carry out their "proper" revolutionary (class) interests, the collapse of communist regimes, the radical increase of women in the work force, and the conflicts of ethnic solidarities and cultural nationalisms throughout the world. Among the responses to these changes are the vast array of "new social movements" that have risen to prominence in the last twenty years (Green parties, gay and 
lesbian liberation movements, and so on), the explosion of a feminist consciousness that valorizes difference as much as equality, and the politics of multiculturalism. ${ }^{9}$

Although they take no universal form, the various expressions of this new "politics of identity" all share the common feature of being constituted by people who previously felt marginalized from dominant political channels and more mainstream social movements..$^{10}$ Significantly, these are also groups and individuals who have been marginalized by prevailing social theoretical accounts for why people act the way they do. Thus, for example, classical theoretical accounts of social movement organizations focus on class interests as a motivating factor for action or "instrumental" calculi to achieve specifically power-oriented goals. But rather than emphasize traditional issues of labor and production, the new politics and movements of identity stress "expressive" goals of "selfrealization" 11 while they attempt positively to restore previously devalued differences (e.g., female care-taking and "being-in-relations"). ${ }^{12}$

To make sense of these striking developments, new theories of action and agency have emerged. These new theories of "identity-politics" have shifted explanations for action from "interests" and "norms" to identities and solidarities, from the notion of the universal social agent to particularistic categories of concrete persons. Based on the assumption that persons in similar social categories and similar life-experiences (based on gender, color, generation, sexual orientation, and so on) will act on the grounds of common attributes, theories of identitypolitics posit that "I act because of who I am," not because of a rational interest or set of learned values.

The study of identity formation is relatively new on the agenda of social theory. When viewed in the context of the enduring conundrum of explaining social action, these new theories of identity are easily recognizable as confrontations with the intractable problems of agency that have long characterized the social sciences: How can we formulate viable sociological accounts of moral action that do not resort to external constraint (or "internalized" external constraint) to explain action that "deviates" from the universalist premises of mainstream theories? The solution that characterizes many of the new approaches to identity formation has been to challenge the putative universalism of the modernist ontology itself, for it is only when judged against this alleged norm that women and other others have been found wanting. The new theoretical perspectives have thus argued that the putative universal 
social actor is in fact extremely particularistic - namely, white, male, and western. Most important, they claim that it is only in the context of this theoretical sleight of hand, one that claims universality for the particularistic and androcentric, that the experiences of others are suppressed, denied, and devalued in the first place. Thus the theoretical response has been not only to reveal the gendered or racially- or classspecific character of the "general" modern social actor. It has also been to propose and envision a theoretical alternative that transforms those very devalued traits of (female or racial) otherness into a newly esteemed ideal of selfhood and normatized social action.

Leading examples of such changes in feminist theory are the wellknown works of Nancy Chodorow and Carol Gilligan. ${ }^{13}$ Gilligan began by confronting the fact that for years scholars of moral development had pondered the seemingly unanswerable question of why women did not achieve the highest stages of development allegedly achieved by men. Social scientists and psychologists alike kept asking: Why are women anomalous to the norm? More specifically, they wanted to know why women putatively were getting "stuck" at a "lower stage" of moral development, while men developed a sense of agency and judgment according to the theoretical social norm - that is, they become increasingly autonomous, individuated, and oriented to rules of abstract justice. Women, by contrast, were believed to be at a lower stage because they were found to have a sense of agency still tied primarily to their social relationships and to make political and moral decisions based on context-specific principles based on these relationships rather than on the grounds of their own autonomous judgments.

Students of gender studies know well just how busy social scientists have been kept by their efforts to come up with ever more sociological "alibis" for the question of why women did not act like men. Gilligan's response was to refuse the terms of the debate altogether. She thus did not develop yet another explanation for why women are "deviant." Instead, she turned the question on its head by asking what was wrong with the theory - a theory whose central premises defines $50 \%$ of social beings as "abnormal." Gilligan translated this question into research by subjecting the abstraction of universal and discrete agency to comparative research into female behavior evaluated on its own terms The new research revealed women to be more "concrete" in their thinking and more attuned to "fairness" while men acted on "abstract reasoning" and "rules of justice." These research findings transformed female otherness into variation and difference - but difference now freed from the normative de- 
valuation previously accorded to it. In so doing, Gilligan contributed not only to a new recognition but to a theoretical and political celebration of the very female identity that prevailing theories had denigrated. ${ }^{14}$

Struggles over identity are thus being framed by the recognition that getting heard requires new theories. Other scholars engaged in identitypolitics are also insisting that there are ways of knowing and defining experience different from but equally valuable as those rendered by the dominant theoretical discourses. Law professor Catherine MacKinnon, for instance, observes that it is difficult for women to stage a revolution using the tools of the oppressor - especially his "words." ${ }^{15}$ Here she sounds like cultural analyst Molefi Kete Asante, when he asks in a similar vein: How can the oppressed use the same theories as the oppressors? ${ }^{16}$ In "The Search for an Afrocentric Method," Asante not only challenges assumptions about the universality of Eurocentric concepts; he also simultaneously restores dignity to the very qualities of otherness by which such theories had previously defined and devalued these same non-western identities. ${ }^{17}$

These theoretical challenges have been pathbreaking. They move away from deriving the meaning of action and the definition of the self from falsely imputed universalities and toward generating concrete notions of social being that begin from difference. This can only improve the prospects for theories of agency. At the same time, however, the virtually simultaneous outcries of "essentialism" directed towards these new identity-politics testify to a whole new set of stubborn conceptual difficulties that they contain. Among the many questions we must ask, for example, is whether the new theories of identity-politics are not creating their own new "totalizing fictions" in which a single category of experience, say gender, will over-determine any number of crosscutting simultaneous differences such as race and class. Does this not run "roughshod" over women who might be "ill-served" by replacing all other forms of difference by the singular one of gender? ${ }^{18}$ Feminists of color charge that feminist identity-theories focusing exclusively on gender oversimplify their situation, because gender is just one of a number of other fundamental facets of identity and difference, such as poverty, class, ethnicity, race, sexual identity, and age. ${ }^{19}$

Another question we must ask is how is it possible to claim these approaches to identity are truly arguing for a social construction of agency, given that they theorize identity from essential (that is, prepolitical) or fixed categories constructed from given attributes - e.g., 
woman, African-American. If identities are fixed there can be no room to accommodate changing power relations - or history itself - as they are constituted and reconstituted over time. One of the most influential of these criticisms has been that directed by Joan Scott against the work of Chodorow and Gilligan. ${ }^{20}$ Scott pointed out that even with a well-deserved refutation of abstract universalism, Chodorow and Gilligan have only substituted their own ahistorical and essentialist notion of "woman." 21 Why, Scott continues to ask, should we assume that "women" will all act the same under all conditions simply because of their biological sex or even their socialized gender-identities? ? $^{22}$ Does that not open up the possibility for a female version of abstract universal agency against which any number of historically different forms of female agency will be held newly "deviant?"

There are also important questions about the allegedly stable content of the new categories of identity. To assume that simply because in some places and in some times women appear to be more morally relational than men in their sense of agency does not in any way support the more general conclusion that all women are more morally relational than men. To be sure, there is abundant evidence that under certain conditions such a generalization could be supported. However, do we really want to accept that these dichotomous concepts of gender distinction really reflect the social world? Is it not just as likely that the theoretical categories of exclusion helped constitute those gender differences in the first place? And if it is indeed the case that female identities are the consequence of categories based on false universality and exclusions, should we not criticize and contest these categorical identities? In short, even assuming the empirical case to be true, is it not a serious mistake to leap from the empirical presence of relational identities to their normative valorization? There is too much evidence of the potentially suffocating and negative effects of "being-in-relations" to accept this move uncritically.

The underlying argument here is that a gender-centered identitypolitics does not take on the real challenge of criticizing, contesting, transforming, indeed escaping from the theoretical dichotomies that buttress and hierarchize forms of difference in the first place. Instead, the new identity-theories reify anew what is in fact a multiplicity of historically varying form of what are less often unified and singular and more often "fractured identities." ${ }^{23}$ Thus although some scholars claim that establishing an identity or expressing self-realization is one of the goals of new social movements, ${ }^{24}$ there are others who consider 
the newly celebrated but fixed categories of identity and self-realization to be newly problematic, regardless of their being informed by the traits of the previously excluded. ${ }^{25}$

Finally, and perhaps most worrisome, we must question the slide from the gendered distinction between a moral and a normative notion of relationality (women are "relational," men are "autonomous") to a gendered distinction in the degree of analytic relationality between men and women. The latter is an impossible conclusion. To be sure, there is evidence to show that many men in some times and places are less morally oriented to relationships than are women; but this is a result of the social, historical, and relational constitution of male identities in these times and places. That is, both men and women must be conceived analytically as being embedded within and constituted by relationships and relationality. Masculine individualism is itself the product of social relationality. Whether the analytic relationality characteristic of both men and women devolves into a universally gendered distinction in empirical or normative relationality must not be presumed a priori but can only be explored empirically and historically.

These are some of the theoretical ambushes contained in the new theories of agency we call identity-politics. In the absence of clearly positive theoretical and epistemological alternatives to the problem of identity, however, such criticisms can have the effect of only tossing theories of social action and identity back and forth between the abstract (white male) universality of the modern individuating agent who starves in a vacuum of abstraction, and the essential "woman" (or black, or Serbian, or gay man) who drowns in a sea of relationality, "experience," and identity. A number of studies from different approaches have therefore begun the task of developing positive theoretical and epistemological alternatives to these two mutually reinforcing opposites. ${ }^{26}$ Fraser and Nicholson articulate the challenge at hand in their suggestion that alternative theories of agency - in this case feminist agency - must

be inflicted by temporality, the historically-specific institutional categories like the modern, restricted, male-headed, nuclear family taking precedence over ahistorical functionalist categories like reproduction and mothering. Where categories of the latter sort were eschewed altogether, they would be genealogized, that is, framed by historical narrative and rendered temporally and culturally specific. ${ }^{27}$

Joining the many others who are struggling to give substance to this directive, I propose linking the concepts of narrative and identity to 
generate a historically constituted approach to theories of social action, agency, and identity.

\section{Introducing narrativity}

I argue above that recent challenges to the long-dominant presuppositions of universal agency have the potential to reify their own culturally and gender-specific identity stories in that they may create a new shade of universalism that contains its own inevitable exclusions. In the task of rethinking a more flexible theory of identity, let us turn to narrative as it has been reframed in current scholarship.

\section{Reframing narrativity}

To consolidate a cohesive self-identity and collective project every knowledge discipline needs an "epistemological other," ${ }^{28}$ For the social sciences, the concept of narrative - with its long association with the humanities profession - holds pride of place in filling that role. Variously formulated in binary terms as idiographic versus nomothetic, particularistic versus generalizable, or description versus theory, the contrast between the "mere narrative" approach of the historians and the more rigorous methodologies of the social sciences has effectively cordoned off narrative from legitimate social-science epistemology. ${ }^{29}$ But a small revolution with potentially large consequences is occurring in our contemporary knowledge culture. ${ }^{30}$ Over the last few decades many historians have lost, abandoned, and even scorned narrative explanation. ${ }^{31}$ At the same time, moreover, a protean reframing of the narrative concept is seeping or being appropriated into the epistemological frameworks of a spectrum of other disciplines - including medicine, social psychology, anthropology, gender studies, law, biology, and physics.

The expressions of this narrative reframing are broad and diverse. One aspect of many of the new works in narrative studies, however, is especially relevant to the increasing sociological attention to identity formation. This is the shift from a focus on representational to ontological narrativity. Before this shift, philosophers of history had argued that narrative modes of representing knowledge (telling historical stories) were representational forms imposed by historians on the chaos of lived experience. ${ }^{32}$ Recently, however, scholars are postulating something much more substantive about narrative: namely, that social life is 
itself storied and that narrative is an ontological condition of social life. Their research is showing us that stories guide action; that people construct identities (however multiple and changing) by locating themselves or being located within a repertoire of emplotted stories; that "experience" is constituted through narratives; that people make sense of what has happened and is happening to them by attempting to assemble or in some way to integrate these happenings within one or more narratives; and that people are guided to act in certain ways, and not others, on the basis of the projections, expectations, and memories derived from a multiplicity but ultimately limited repertoire of available social, public, and cultural narratives. ${ }^{33}$

But there is a paradox. On the one hand, social scientists have by and large kept their distance from these approaches to narrativity. ${ }^{34}$ Yet, on the other hand, sociology has long shown an interest in theorizing about the very themes addressed in studies of identity formation - the study of meaning, social action, social agency, and most recently, collective identity. Indeed, the last two decades have been notable for the number of heroic efforts by sociologists to recast social analysis along the central axes of the interaction between agency and structure, that is, to develop a social theory that allows for human action that is nonetheless bounded and constrained by structural restraints. ${ }^{35}$

There are two reasons for this paradoxical distancing from the new narrative studies on the part of social scientists. The first is that social scientists overwhelmingly limit their conception of the term "narrative" to that of a representational form/method of presenting social and historical knowledge. And it is through this methodological debate over what counts as valid explanation that social scientists have most forcefully separated themselves from the humanities. As long as this representational definition prevails, then, social scientists - in order to be social scientists - must continue to view narrative as the epistemological other and in symbolic contrast to causal explanation. Indeed to the extent sociologists have engaged with narrative studies, the dialogue often recreates the familiar Manichean dichotomy between socialscience explanation and the narrative other. Whether in favor or disparagement, the encounters between sociology and narrative analysis seem inevitably to result in counterposing narrative to causality. Steven Seidman, for example, recently criticized the "foundational obsessionalism" of mainstream sociological theory while demonstrating his support for an understanding of social theory as "narrative with a moral intent." ${ }^{36}$ Seidman is a sociologist who strongly endorses the turn to 
narrative. Nonetheless, in his association of narrative with "story-telling particularism," he straps it into an unnecessary opposition to, and ultimately distancing from, the social sciences ${ }^{37}$ Linking identity and action research to narrative analysis directs our attention to the new ontological dimension of narrative studies and away from the traditional rendering of narrative as a method or form of representation.

The second reason for the neglect of the recently reframed narrativism follows directly from the self-identity project of the social sciences. The study of identity formation touches on the area of ontology - a theory of being - and this is altogether different from general social science approaches to agency and action. From their inception, the social sciences have been concerned with what one political scientist calls the "primacy of epistemology," 38 or the eclipsing of discovery and ontology by the context of justification. ${ }^{39}$ The latter comprises the standards we use to know about the world, the grounds we rely upon to legitimate these foundations of knowledge, the validity of competing methodologies, and the criteria for viable explanations. Discovery and ontology, on the other hand, refer to problem-formation and social being respectively. Both are seen as better left to speculative philosophers or psychologists. The consequences of this division of labor for a sociology of action are significant: 1) issues of social being, identity, and ontology are excluded from the legitimate mainstream of sociological investigation, and 2) the social sciences focus their research on action and agency by studying primarily observable social behavior - measured variously by social interests, rational preferences, or social norms and values - rather than by exploring expressions of social being and identity. Therefore, precisely to the extent that sociologists are aware that the recent focus of narrative studies is toward issues of identity and ontology, these same studies are defined as beyond and outside the boundaries of appropriate social-science concern. ${ }^{40}$

I argue in this article that the association of identity and ontology with philosophy or theoretical psychology on the one side, and action with interests, norms, or behavior on the other, is a limited model and deprives social scientists of the deeper analysis that it is possible to achieve by linking the concepts of action and identity. To get these benefits, however, we must reject the decoupling of action from ontology, and instead accept that some notion of social being and social identity is, willy-nilly, incorporated into each and every knowledgestatement about action, agency, and behavior. Just as sociologists are not likely to make sense of action without focusing attention on struc- 
ture and order, it is unlikely we can interpret social action if we fail to also emphasize ontology, social being, and identity. ${ }^{41}$ We thus enlarge our analytical focus when we study social action through a lens that also allows a focus on social ontology and the social constitution of identity. ${ }^{42}$ The reframing of narrative allows us to make that enlargement.

From diverse sources it is possible to identify four features of a reframed narrativity particularly relevant for the social sciences: 1) relationality of parts, 2) causal emplotment, 3) selective appropriation, and 4) temporality, sequence, and place. ${ }^{43}$ Together, these dimensions suggest narratives are constellations of relationships (connected parts) embedded in time and space, constituted by causal emplotment. Unlike the attempt to produce meaning by placing an event in a specified category, narrativity precludes sense-making of a singular isolated phenomenon. Narrativity demands that we discern the meaning of any single event only in temporal and spatial relationship to other events. Indeed, the chief characteristic of narrative is that it renders understanding only by connecting (however unstably) parts to a constructed configuration or a social network of relationships (however incoherent or unrealizable) composed of symbolic, institutional, and material practices. ${ }^{44}$

The connectivity of parts is precisely why narrativity turns "events" into episodes, whether the sequence of episodes is presented or experienced in anything resembling chronological order. This is done through "emplotment." It is emplotment that gives significance to independent instances, not their chronological or categorical order. And it is emplotment that translates events into episodes. As a mode of explanation, causal emplotment is an accounting (however fantastic or implicit) of why a narrative has the story line it does. ${ }^{45}$ Causal emplotment allows us to test a series of "plot hypotheses" against actual events, and then to examine how - and under what conditions - the events intersect with the hypothesized plot. ${ }^{46}$ Without emplotment, events or experiences could be categorized only according to a taxonomical scheme. Yet, we do not act on the basis of categories or attributes. Polkinghorne implicitly addresses the difference between emplotment and categorization when he notes that social actions should not be viewed as a result of categorizing oneself ("I am 40 years old; I should buy life insurance") but should be seen to emerge in the context of a life-story with episodes ("I felt out of breath last week, I really should start thinking about life insurance") ${ }^{47}$ Similarly, it is also apparent that serious mental confusion or political emotion rarely stems from the inability to place an event or instance in the proper category. Rather we 
tend to become confused when it is impossible or illogical to integrate an event into an intelligible plot. ${ }^{48}$ To make something understandable in the context of a narrative is to give it historicity and relationality. This works for us because when events are located in a temporal (however fleeting) and sequential plot we can then explain their relationship to other events. Plot can thus be seen as the logic or syntax of narrative. ${ }^{49}$

The significance of emplotment for narrative understanding is often the most misunderstood aspect of narrativity. Without attention to emplotment, narrativity can be misperceived as a non-theoretical representation of events. Yet it is emplotment that permits us to distinguish between narrative on the one hand, and chronicle or annales, on the other. ${ }^{50}$ In fact, it is emplotment that allows us to construct a significant network or configuration of relationships.

Another crucial element of narrativity is its evaluative criteria. ${ }^{51}$ Evaluation enables us to make qualitative and lexical distinctions among the infinite variety of events, experiences, characters, institutional promises, and social factors that impinge on our lives. Charles Taylor, for example, argues that the capacity to act depends to a great extent on having an evaluative framework shaped by what he calls "hypergoods" (a set of fundamental principles and values). ${ }^{52}$ The same discriminatory principle is true of narrative: in the face of a potentially limitless array of social experiences deriving from social contact with events, institutions, and people, the evaluative capacity of emplotment demands and enables selective appropriation in constructing narratives. ${ }^{53} \mathrm{~A}$ plot must be thematic. ${ }^{54}$ The primacy of this narrative theme or competing themes determines how events are processed and what criteria will be used to prioritize events and render meaning to them. Themes such as "husbands as breadwinners," "union solidarity," or "women must be independent above all" will selectively appropriate the happenings of the social world, arrange them in some order, and normatively evaluate these arrangements. ${ }^{55}$

\section{Four dimensions of narrativity}

These relatively abstract formulations of narrativity can now be expressed as four different dimensions of narrative - ontological, public, conceptual, and metanarrativities. 
Ontological narratives. These are the stories that social actors use to make sense of - indeed, to act in - their lives. Ontological narratives are used to define who we are; this in turn can be a precondition for knowing what to $d o .{ }^{56}$ This "doing" will in turn produce new narratives and hence, new actions; the relationship between narrative and ontology is processual and mutually constitutive. Both are conditions of the other; neither are a priori. Narrative location endows social actors with identities - however multiple, ambiguous, ephemeral, or conflicting they may be (hence the term narrative identity). To have some sense of social being in the world requires that lives be more than different series of isolated events or combined variables and attributes. Ontological narratives process events into episodes. People act, or do not act, in part according to how they understand their place in any number of given narratives - however fragmented, contradictory, or partial. Charles Taylor puts it this way: "because we cannot but orient ourselves to the good, and thus determine our place relative to it..., we must inescapably understand our lives in narrative form...." ${ }^{57}$

But ontological narrativity, like the self, is neither a priori nor fixed. Ontological narratives make identity and the self something that one becomes. ${ }^{58}$ Thus narrative embeds identities in time and spatial relationships. Ontological narratives affect activities, consciousness, and beliefs and are, in turn, affected by them. ${ }^{59}$ Like all narratives, ontological narratives are structured by emplotment, relationality, connectivity, and selective appropriation. So basic to agency is ontological narrativity that if we want to explain - that is, to know, to make sense of, to account for, perhaps even to predict, anything about the practices of social and historical actors, their collective actions, their modes and meanings of institution-building and group-formations, and their apparent incoherencies - we must first recognize the place of ontological narratives in social life.

But where do ontological narratives come from? How are people's stories constructed? Ontological narratives are, above all, social and interpersonal. Although psychologists are typically biased toward the individual sources of narrative, even they recognize the degree to which ontological narratives can only exist interpersonally in the course of social and structural interactions over time ${ }^{60}$ To be sure, agents adjust stories to fit their own identities, and, conversely, they will tailor "reality" to fit their stories. The intersubjective webs of relationality sustain and transform narratives over time. Charles Taylor calls these "webs of interlocution," others call them "traditions," I call them "public narratives." 61 
Public Narratives. Public narratives are those narratives attached to cultural and institutional formations larger than the single individual, to intersubjective networks or institutions, however local or grand, microor macro-stories about American social mobility, the "freeborn Englishman," the working-class hero, and so on. Public narratives range from the narratives of one's family, to those of the workplace (organizational myths), church, government, and nation. ${ }^{62}$ Like all narratives, these stories have drama, plot, explanation, and selective criteria. Families, for example, selectively appropriate events to construct stories about their descent into poverty. The mainstream media arrange and connect events to create a "mainstream plot" about the origin of social disorders. The seventeenth-century church explains the theological reasons for a national famine. Government agencies tell us "expert" stories about unemployment. Taylor emphasizes the centrality of public to ontological narrative when he states:

\begin{abstract}
We may sharply shift the balance in our definition of identity, dethrone the given, historical community as a pole of identity, and relate only to the community defined by adherence to the good (or the saved, or the true believers, or the wise). But this doesn't sever our dependence on webs of interlocution. It only changes the webs, and the nature of our dependence..$^{63}$
\end{abstract}

Metanarrativity. This third dimension of narrativity refers to the "masternarratives" in which we are embedded as contemporary actors in history and as social scientists. ${ }^{64}$ Our sociological theories and concepts are encoded with aspects of these master narratives - Progress, Decadence, Industrialization, Enlightenment, etc. - even though they usually operate at a presuppositional level of social-science epistemology or beyond our awareness. These narratives can be the epic dramas of our time: Capitalism vs. Communism, the Individual vs. Society, Barbarism/Nature vs. Civility. They may also be progressive narratives of teleological unfolding: Marxism and the triumph of Class Struggle, Liberalism and the triumph of Liberty, the Emergence of Western Citizenship, the Rise of Nationalism or of Islam. The master narrative of Industrialization/Modernization out of Feudalism/Traditional Society is one of the most outstanding examples of how a metanarrative becomes lodged in the theoretical core of social theory.

Perhaps the most paradoxical aspect of metanarratives is their quality of denarrativization. That is, they are built on concepts and explanatory schemes ("social systems," "social entities," "social forces") that are in themselves abstractions. Although metanarratives have all the necessary components of narrativity - transformation, major plot lines and 
causal emplotment, characters and action - they nonetheless miss the crucial element of a conceptual narrativity. ${ }^{65}$

Conceptual narrativity. These are the concepts and explanations that we construct as social researchers. Because neither social action nor institution-building is solely produced through ontological and public narratives, our concepts and explanations must include the factors we call social forces - market patterns, institutional practices, organizational constraints. The challenge of conceptual narrativity is to devise a vocabulary that we can use to reconstruct and plot over time and space the ontological narratives and relationships of historical actors, the public and cultural narratives that inform their lives, and the crucial intersection of these narratives with the other relevant social forces. ${ }^{66}$ To date, few if any of our analytic categories are in themselves temporal and spatial. ${ }^{67}$ Rather, our modern sociological use of terms such as "society," the "actor," and "culture" is for social-science purposes intentionally abstracted from their historicity and relationality. The conceptual challenge that narrativity poses is to develop a social analytic vocabulary that can accommodate the contention that social life, social organizations, social action, and social identities are narratively, that is, temporally and relationally, constructed through both ontological and public narratives. ${ }^{68}$

\section{The conceptual implications of the new narrative}

So far, I have elaborated some of the dimensions of narrative analysis and have identified the major types of narrativity. What, then, are the implications of this conception of narrative for identity formation and social theory? How can narrativity help us understand social life and social practices? Although all four kinds of narrativity are relevant to social theory, it is the fourth that is the most important if theories are adequately to account for social action and collective projects. This is because conceptual narrativity is defined by temporality, spatiality, and emplotment, as well as relationality and historicity. If narrative is indeed a constitutive feature of social life, the first analytic challenge is to develop concepts that will allow us to capture the narrativity through which agency is negotiated, identities are constructed, and social action mediated. ${ }^{69}$ In the next section I suggest two central components of conceptual narrativity: narrative identity and relational setting. 


\section{Narrative identity}

The concept of a narrative identity dovetails with the move of identitypolitics to reintroduce previously excluded subjects and suppressed subjectivities into theories of action. At the same time, however, the narrative identity approach firmly rejects the tendencies of identity theories to normatize new categories that are themselves as fixed and removed from history as their classical predecessors. The approach builds from the premise that narrativity and relationality are conditions of social being, social consciousness, social action, institutions, structures, even society itself; the self and the purposes of self are constructed and reconstructed in the context of internal and external relations of time and place and power that are constantly in flux. That social identities are constituted through narrativity, social action is guided by narrativity, and social processes and interactions - both institutional and interpersonal - are narratively mediated provides a way of understanding the recursive presence of particular identities that are, nonetheless, not universal.

The importance of conceptual narrativity is therefore that it allows us to build upon the advances and simultaneously to transcend the fixity of the identity concept as it is often used in current approaches to social agency. Joining narrative to identity reintroduces time, space, and analytical relationality - each of which is excluded from the categorical or essentialist approach to identity. While a social identity or categorical approach presumes internally stable concepts, such that under normal conditions entities within that category will act uniformly and predictably, the narrative identity approach embeds the actor within relationships and stories that shift over time and space. It thus precludes categorical stability in action. These temporally and spatially shifting configurations form the relational coordinates of ontological, public, and cultural narratives. Within these temporal and multilayered narratives identities are formed; hence narrative identity is processual and relational. In this sense, the narrative identity approach shares much with the relational epistemologies most associated with Harrison White. ${ }^{70}$

The analytic relationality of the narrative identity concept is also at odds with the normative relationality of theories of identity-politics. Feminist identity-politics, for example, see relationality as a normative and concrete ontology. First it is argued that women are socialized to be more relational than men. Then a normative leap is made to argue 
that this quality of "being-in-relations" in turn makes women more "caring" and more humane. In the narrative identity perspective, by contrast, relationality is used only analytically - that is, all identities (male and female) must be analyzed in the context of relational and cultural matrices because they do not "exist" outside of those complexes. ${ }^{71}$ Individualism, after all, is itself socially and relationally constructed. At the same time, this analytic relationality tells us nothing in advance about the value or quality of those relationships and relational identities. The meaningful implications of a narrative concept of identity can only be determined by empirical inquiry, not by a priori assumptions. In other words, to say that identities are forged only in the context of ongoing relationships that exist in time, space, and emplotment, is not to say that "being-in-relationship" is somehow "better" or "worse" than the individuating notions of agency. It is, rather, to divest conceptual narrativity of any particular normative implications. The interdependence and connectivity of parts characteristic of narrative analysis makes relationality an analytic variable instead of an ideal type or normative stand-in for an unchanging sense of "community." Relationships may be more or less bonded, the experience of them may be more or less constricting or enabling - but again, this is a question of narrative contingency, not utopian ideals. ${ }^{72}$

A compelling illustration of the narrative identity concept can be found in Steedman's widely-read sociological autobiography of her English working-class childhood in the $1950 \mathrm{~s} .{ }^{73}$ According to the dominant scholarly accounts, the extreme poverty of mid-century English working-class life was compensated by a robust "independence, pride, and sense of community." ${ }^{74}$ Sociologists have long assumed that working-class experience did in fact conform to this depiction of working-class identity. Steedman's narrative shatters all of our assumptions about the attributes of identity and agency that should normally fit with this form of social categorization of working-class life. She presents us, instead, with an aching picture of the "class longings," and narratives of envy and desire (that life might be different), that characterized her life of underprivileged exclusion from the dominant culture. Steedman's representations of identities constructed of emotional and material poverty unfold sociologically in the context of the relational complexity in which her life was embedded, and in the narratives she inherited from her mother's life - ones in which gender intersected with class and so transformed the usual traits attributed to both of those categorical identities. ${ }^{75}$ 
The narrative contingency of identity is similarly vividly suggested in Davis's historical sociology of the notorious "one-drop rule" in racial classification. ${ }^{76}$ Davis's study demonstrates the numerous conflicts that accompanied the rule of a type of racial classification that failed to take into account the historical intermingling of different races. By declaring that anyone with even a drop of African blood was a "Negro," the burden of proving one's identity - for blacks and whites - makes it obvious that such a binary classification is too rigid to account for those whose lives failed to conform to the dominant public accounts of racial purity and segregation. The irony was that the very people or groups who deliberately created racial classifications in the first place often could not even identify correctly those individuals they wanted to classify; obviously skin color was now a poor indicator of race. The impact of America's imaginative one drop rule went beyond public and private struggles over personal identity. By compelling all children of mixed blood to live in the black community, "the rule made possible the incredible myth among whites that miscegenation had not occurred, that the races had been kept pure in the south." ${ }^{17}$ The problem of who gets to define a person continues even today. One of the key decisions many principal investigators make about research projects concerning race is whether their interviewers should identify the race of respondents or whether the persons being interviewed should get to choose their race from a preselected category.

Class-formation theory provides another example of the concept of narrative identity for theoretical rethinking. ${ }^{78}$ Class-formation theory has traditionally explained action with the concept of interest or with universal rational preferences. Since interest is determined by the logic and stages of socioeconomic development, the social analyst imputes a set of predefined interests or values to people as members of social categories (e.g., traditional artisan, modern-factory worker, peasant). Historians commonly argue, for instance, that the decline of traditional domestic modes of production and its concomitant threat to custom created an "artisanal interest" from which explanations for social movements can at least in part be derived. Although social science historians almost always demonstrate with subtlety how these interests are mediated through intervening factors (culture, gender, religion, residential patterns, etc.), the interests remain the foundational explanation for working-class practices and protests. Making sense of social action thus becomes an exercise in placing people into the right social categories by identifying their putative interests, and then doing the empirical work of looking at variations among those interests. 
T. H. Marshall, for example, in his classic study of citizenship, correlated the stages of citizenship's development with epochs of class formation; each state represented the expression of the interests of an emerging historic class. ${ }^{79}$ Underpinning his argument is the assumption that actors within the same category ("the working-class" "the gentry," "capitalist employers," "state bureaucrats") will have shared attributes hence shared interests directing them to have similar citizenship practices. Naturally, this assumption leads us to expect intra-class uniformity throughout each period of citizenship-formation: All the members of a single category of actors - the eighteenth-century English "working class," for example - should behave similarly and have the same interests with respect to citizenship regardless of differences of residence, family, or gender.

But why do we premise or limit our understanding of people to their work category? Why should we assume that an individual or a collectivity has a particular set of interests simply because one aspect of their identity fits into one social category - in this case their place in the production process? To let "class" stand as a proxy for experience is to presume what has not been empirically demonstrated - namely that identities are foundationally constituted by their categorization in the division of labor.

Substituting the concept of narrative identity for that of interest circumvents this problem. A narrative identity approach assumes that social action can only be intelligible if we recognize that people are guided to act by the structural and cultural relationships in which they are embedded and by the stories through which they constitute their identities - and less because of the interests we impute to them. Whereas interest derives from how we as analysts categorize people's role in a division of labor, the narrative-identity approach emphasizes how we characterize or locate people within a processual and sequential movement of relationships and life-episodes. Whereas an interest approach assumes people act on the basis of rational means-ends preferences or by internalizing a set of values, a narrative identity approach assumes people act in particular ways because not to do so would fundamentally violate their sense of being at that particular time and place. ${ }^{80}$ In another time or place, or in the context of a different set of prevailing narratives, that sense of being could be entirely different because narrative identities are constituted and reconstituted in time and over time. Calhoun demonstrates this in his narrative about how Chinese students, who had initially displayed no interest in politics, formed 
cohesive political identities during the one month they were thrust into the overpowering drama of Tienanmen Square. ${ }^{81}$

The "narrative" dimension of identity there and elsewhere, thus presumes that action can only be intelligible if we recognize the various ontological and public narratives in which actors are emplotted. Narrative identities are constituted by a person's temporally and spatially variable place in culturally constructed stories composed of (breakable) rules, (variable) practices, binding (and unbinding) institutions, and the multiple plots of family, nation, or economic life. Most important, however, narratives are not incorporated into the self in any direct way; rather they are mediated through the enormous spectrum of social and political institutions and practices that constitute our social world. People's experiences as workers, for example, are inextricably interconnected with the larger matrix of relations that shaped their lives their regional location, the practical workings of the legal system, family patterns - as well as the particular stories (of honor, of ethnicity, of gender, of local community, of greed, etc.) used to account for the events happening to them..$^{82}$

\section{Relational setting}

Another challenge of conceptual narrativity is to develop a vocaculary that will allow us to locate actors' social narratives in temporal and spatial configurations of relationships and cultural practices (institutions and discourses). We need concepts that will enable us to plot over time and space the ontological narratives of historical actors, the public and cultural narratives that inform their lives, as well as the relevant range of other social forces - from politics to demographics - that configure together to shape history and social action. We thus need a conceptual vocabulary that can relate narrative identity to that range of factors we call social forces - market patterns, institutional practices, organizational constraints, and so on.

Society is the term that usually performs this work of contextualization in social analysis. When we speak of understanding social action, we simultaneously speak of locating the actors in their "societal" context. But society as a concept is rooted in a falsely totalizing and naturalistic way of thinking about the world. For most practicing social-science research, a society is a social entity. As an entity, it has a core essence an essential set of social springs at the heart of the mechanism. This 
essential core is in turn reflected in broader co-varying societal institutions that the system comprises. Thus, when sociologists speak of feudalism, for example, we mean at once "feudal society" as a whole, a particular set of "feudal class relations" at the core of this society, a "feudal manorial economy," and a concomitant set of "feudal institutions" such as feudal political units and feudal peasant communities. Most significantly for historical research, institutions within a society must co-vary with each other. Thus in "feudal societies," the state by definition must be a feudal state whose feudal character co-varies with all other feudal institutions; feudal workers must all be unfree and extra-economically exploited peasants. And in "industrial society," a "modern industrial/capitalist" state must be detached from civil society and the industrial economy, and industrial workers must be individual and legally free. To be sure, the synchrony is not always perfect. In periods of transition from one society to another, there occurs a "lag effect" and remnants of the old order persist against the pressures of the new. But despite these qualifications, the systemic metaphor assumes that the parts of society co-vary along with the whole as a corporate entity.

To make social action intelligible and coherent, these systemic typologies must be broken apart and their parts disaggregated and reassembled on the basis of relational clusters. For a social order is neither a naturalistic system nor a plurality of individuals, but rather a complex of contingent cultural and institutional relationships. If we want to be able to capture the narrativity of social life we need a way of thinking that can substitute a relational imagery for a totalizing one. I thus agree with Tilly and White who both concur in their own way with Michael Mann who writes: "It may seem an odd position for a sociologist to adopt; but if I could, I would abolish the concept of "society" altogether." ${ }^{83}$ Substituting the metaphor of a relational setting for "society" makes this possible. ${ }^{84} \mathrm{~A}$ relational setting is a pattern of relationships among institutions, public narratives, and social practices. As such it is a relational matrix, a social network. ${ }^{85}$ Identity-formation takes shape within these relational settings of contested but patterned relations among narratives, people, and institutions.

One of the most important characteristics of a relational setting is that it has a history, and thus must be explored over time and space. ${ }^{86} \mathrm{~A}$ relational setting is traced over time not by looking for indicators of social development, but by empirically examining if and when relational interactions among narratives and institutions appear to have pro- 
duced a decisively different outcome from previous ones. Social change, from this perspective, is viewed not as the evolution or revolution of one societal type to another, but by shifting relationships among the institutional arrangements and cultural practices that constitute one or more social settings.

Spatially, a relational setting must be conceived with $c$ geometric rather than a mechanistic metaphor, because it is composed of a matrix of institutions linked to each other in variable patterns contingent on the interaction of all points in the matrix. A setting crosses "levels" of analysis and brings together in one setting the effect of, say, the international market, the state's war-making policies, the local political conflicts among elites, and the community's demographic practices of a community - each of which takes social, geographical, and symbolic narrative expression. This cross-cutting character of a relational setting assumes that the effect of any one level (for example, the labor-market sector) can only be discerned by assessing how it is affected interactively by the other relevant dimensions, such as gender and race. To do so requires that we first disaggregate the parts of a setting from any presumed covarying whole and then reconfigure them in their temporal and geographic relationality. In this way, for example, different regions of a single nation-state are no longer cast as variants of a single society, but as different relational settings that can be compared. ${ }^{87}$

\section{Conceptual narrativity and theories of action and agency}

\section{Narrative identity and social meaning}

One major advantage of the concept of narrative identity is in the challenge it poses to the false dichotomy too often posed between ideal versus instrumental meanings of action ${ }^{88}$ Some sociologists claim that action is only authentic when it is expressive rather than instrumental. To enforce the point, material goals - such as bread and wages - are typically called instrumental while ideal activities are usually associated with qualitative concerns in daily life. Weber, for instance, argued that if wages were of secondary importance for German workers, that was evidence of the superiority of ideal action ${ }^{89}$ From the same assumptions, neo-classical economists go to equal lengths to provide support for the primacy of self-interest among workers in order to support the concept of rational action. And most currently, it is theorists of the new identity-politics who distinguish the new social movements (from the old) by their putatively exclusively ideal - hence, identity - focus. ${ }^{90}$ 
Yet from a narrative identity perspective there is nothing self-evident about the instrumental nature of wage demands any more than that of the ideal nature usually attributed to cultural activities. When we look at wage-struggles, for instance, as part of an a priori system of categorization, we inevitably classify them as expressions of instrumental goals. But when we view these same wage-struggles through the lens of a narrative identity analysis, we are immediately impressed by the difficulty of classifying them as solely either instrumental or ideal. Wages served every purpose from maintaining social honor, to preserving families, to asserting independence in the face of newly imposed factory regimes. Historical studies demonstrate the vast range of variation in the use of bread and wages. Indeed, if there is any common narrative theme that emerges from these studies, it is that wage-struggles appear to be most commonly viewed as a form of provisioning - a characteristic social activity that defies either ideal or instrumental classification in its focus on maintaining relational continuities over time and within space. ${ }^{91}$

Many examples defy attempts to periodize or categorize instrumental (material) versus ideal (identity) ends. Joyce, for example, has collected an array of studies illustrating the remarkable variation in "the historical meanings of work." ${ }^{92}$ It is not just that work signified honor as much as livelihood; equally important, even when money wages were at stake, it was impossible to separate their narrative value from that of the "dignity of the trade. ${ }^{.93}$ Many years ago Smelser demonstrated that collective movements aimed at factory reform (surely the quintessential "instrumental" object) were motivated by working families' efforts to hold the family together against the destabilizing impact of women and children's factory labor. ${ }^{94}$ And when nineteenth-century working people demanded the vote on the grounds of their "property in labor," it was not the autonomous workmanship ideal of Locke on which they founded these claims, but on the relational property of apprenticeship - a form of judicial citizenship and community solidarity. ${ }^{95}$

The meaning imputed to the appropriation of material life should not, therefore, be presumed until historically explored. Just as an adequate material life is an essential means of preserving normative relations, so cultural and symbolic relations provide material resources for livelihood. ${ }^{96}$ Similarly, so-called instrumental strategies and identity politics appear to be increasingly linked in research findings about the new social movements. ${ }^{97}$ 
The narrative identity concept allows us to make this shift in the interpretation of action from an a priori categorization to a focus on contingent narratives of meaning. The example of the conceptual shift from ideal versus instrumental agency to the concept of provisioning, for example, strikingly supports the switch from fixed notions of agency to relational analyses of identity formation. If persons are socially constituted over time, space, and through relationality, then others are constitutive rather than external to identity. From this perspective authentic social action can readily encompass institutional practices that organize social inclusions and institutional exclusions - such as trade unions or community associations. ${ }^{98}$ Historical and contemporary studies indeed suggest that structural, and sometimes normative, autonomy was more often than not contingent upon the grids of social relationality (everything from collective memories, to political power and policies from above, to competing social claims, to pasts and futures of intractable social connections, and public narratives) that variably adhere to the interstices of an individual life. ${ }^{99}$ These institutional and symbolic relationships are no mere external set of norms to be "stripped away by the sociologist" to discover the "real analytic self"; they are not "internalized" sets of societal rules residing within the human being. ${ }^{100}$ Rather they are constitutive to self, identity, and agency. Consider the comments of one late eighteenth-century English artisan on some of the progressive French notions of liberty that threatened to dismantle regulative welfare policies:

It cannot be said to be the liberty of a citizen, or of one who lives under the protection of any community; it is rather the liberty of a savage; therefore he who avails himself thereof, deserves not that protection, the power of society affords. ${ }^{101}$

For this individual, others were not part of the external problem of constraint but constitutive - for good or for bad - of his narrative identity.

Race, gender, and power

Although social action may be only intelligible through the construction, enactment, and appropriation of narratives, this does not mean that social actors are free to fabricate narratives at will. Rather, there is only a limited repertoire of available representations and stories. Which kinds of narratives will socially predominate is contested politically and will depend in large part on the distribution of power. This is 
why the kinds of narratives people use to make sense of their situations will always be an empirical rather than a presuppositional question. It is essential, in other words, that we explicate, rather than assume or take for granted, the narratives of groups and persons. The extent and nature of any given repertoire of narratives available for appropriation is always historically and culturally specific; the particular plots that give meanings to those narratives cannot be determined in advance.

Since social actors do not freely construct their own private or public narratives, we can also expect to find that confusion, powerlessness, despair, victimization, and even madness are some of the outcomes of an inability to accommodate certain happenings within a range of available cultural, public, and institutional narratives. Thus, in everyday talk we often characterize incoherent experiences - and especially those where we feel controlled by a greater power than our own - as "Kafkaesque." ${ }^{102}$ For this reason, gender studies and critical race theories have eagerly argued for the importance of constructing new public narratives and symbolic representations that do not continue the long tradition of exclusion so characteristic of dominant ones.

Patrizia Violi, for example, reminds us how critical the presence or absence of particular kinds of narratives have been to the construction of both male and female subjectivities. ${ }^{103}$ The archetypical "universal" narrative allows men to objectivize themselves and their own experiences in these everyman stories - stories that not only represent maleness, but in effect replicate the metanarratives of classical social theory. In pointing out that women do not have available to them the same normatively valued forms of symbolic representation - especially stories of solidarity and autonomy among women - Violi notes the difficulties for women in constructing social identities. These representational silences are therefore tantamount to keeping invisible not only the differences between men and women but also the very subjectivities of women themselves. Seeing representation, narrative, and subjectivity as part of the same process, Violi argues that unless female subjectivity is made visible through narrative "it will remain confined within the closed space of individual experience." 104 Choosing narratives to express multiple subjectivities is a deliberate way of rejecting the neutrality and appearance of objectivity typically embedded in master narratives.

Steedman's analytic autobiography of her English working-class roots is among the most powerful examples of the significance of alternative 
public narratives in countering the potential damage to identity formation caused by singular dominant narratives. ${ }^{105}$ The public narratives of working-class community she had available as a child omitted women, just as many of the current feminist accounts of identity omit class and poverty. ${ }^{106}$ In this context of narrative silence toward her own experiences, Steedman presents a picture of a self's (her mother's) absolute longing and absence. Challenging the silence, Steedman articulates a counter-narrative - one that joins gender and class, with many other relational complexities of English life - and thus lays the groundwork for a newly reconstructed kind of narrative identityformation.

Struggles over narrations are thus struggles over identity. In an examination of their legal training, for instance, Patricia Williams and Charles Lawrence explicitly reject silencing the human voice in order to produce "abstract, mechanistic, professional, and rationalist" legal discourse ${ }^{107}$ Embracing the notion of multiple subjectivity, Williams tells us that she does not use the "traditionally legal black-letter vocabulary," because she is "intentionally double-voiced and relational." 108 Lawrence calls this kind of multiple consciousness by another name - "dual subjectivity" "109 Either way, these scholars of color contend that writing counter-narratives is a crucial strategy when one's identity is not expressed in the dominant public ones. It is not surprising then that the narratives of excluded voices reveal "alternative values" since narratives "articulate social realities not seen by those who live at ease in a world of privilege." ${ }^{110}$ The centrality of ontological narrative in the construction of social identities is also revealed in a story Williams tells about starting law school at Harvard University. With "secretive reassurance," Williams recalls, her mother explained why she knew the young black student would succeed at the prestigious university. "The Millers were lawyers, so you have it in your blood." 111 Encoded in that story about the white slave holder (Attorney Austin Miller) who had purchased and impregnated Williams' great-greatgrandmother was the proof that a category is neither fixed nor nonrelational. If "one drop" of blood could be constructed into a narrative to dominate one sector of the population, could the story not also be inverted so that now encoded in that single drop of blood is a narrative of empowerment? 
Conceptual narrativity also allows us to think differently about the relationship between social classes and political action. Recall the earlier example from T.H. Marshall in which he assumed a correlation between class attributes and political action toward citizenship formation. ${ }^{112}$ Relational and narrative approaches can be brought to bear on the same evidence to show otherwise. Even though eighteenth-century English working people certainly shared important attributes - they were propertyless in most respects, exploited by their employers, and working for wages - their conditions and degrees of empowerment with respect to citizenship were not uniform but varied dramatically across the social and geographical landscape. The "same" working class differed radically as to whether they even perceived the laws of citizenship to be rights in the first place. Neither class nor status divisions can account for these differences since those in similar class situations maintained different degrees of power across regions.

From the narrative identity perspective, these same working classes would be seen as members of political cultures whose symbolic and relational places in a matrix of narratives and relationships are better indicators of action than their categorical classifications. From this angle of relational membership, identities cannot be derived from attributes imputed from a stage of societal development (be it pre-industrial or modern), or by "experience" imputed from a social category (such as traditional artisan, factory laborer, or working-class wife), but by actors' places in the multiple (often competing) symbolic and material narratives in which they were embedded or with which they identified. ${ }^{113}$ We would thus no longer assume that a group of people have any particular relationship to citizenship simply because one aspect of their identity fits into a single category known as the "working class." Social action thus loses its categorical stability, and group embeddedness and cultural representations become more important than class attributes - thus directing us to investigate citizenship-identities by looking at actors' places in their relational settings, or what Bourdieu would call a "habitus." 114 As a general proposition, this would direct us to expect greater contingencies of agency. We would be considerably less concerned with "deviation" and more fascinated by variation.

This shift would in turn allow us to make sense of a situation in which even though a large group of English people could be similarly categorized as "working-class" - in that they shared working-class attri- 
butes (lack of ownership of means of production, landlessness, and so on) - their political activities and identities varied radically depending upon their settings. ${ }^{115}$ In the case of eighteenth-century England the effects usually attributed to proletarianization were in fact overdetermined in many instances by particular narrative relationships and institutional practices (including national apprenticeship laws, the participatory rules and expectations of enforcement, the durability of particle inheritance, the local control and symbolic meaning attached to skilled work, and the skilled practices of affiliation). In a context configured by these relationships, certain working communities were able to offset many of the "normal" consequences of propertylessness with a more powerful form of "property" in association and membership. ${ }^{116}$

\section{Conclusion}

Modern social theories of universal agency have made many of the data of human activity inexplicable. Until recently, women, non-westerners, and minorities frequently were defined in social anlaysis (often inadvertently) as irrational, anomalous, or deviant from modern social action. Consider, for example, the "problem" of those nineteenth-century working-class movements that deviated from Marxist predictions of revolutionary class consciousness when they demanded state intervention to protect their rights. All too frequently, these movements have been labeled by historians and sociologists as "reformist" or as victims of "social control" and "false consciousness." This barely conceals a hidden contempt for those putatively duped objects of history who acted differently from the way the universal modern class actor would. Yet as long as we continue to conceptualize others as sources of external constraint, we are forced to label such relational and institutionally-oriented goals as "backwards-looking," "reactionary," or as evidence of social control. ${ }^{117}$ Action and agency that fail to conform to the postulates of the universal norms of agency are often explained by the external power of order, or internalized institutional constraint - be it norms or social laws, bureaucratic power, or economic forces. Why? Because the dispossessed ghost-like individual self is "less liberated than disempowered." 118 Indeed, one could go further; such a person cannot - even heuristically - exist. If an aim of the social sciences is to generate explanations for action that are indeed intelligible, the capacity of social-science logic to lay the basis for achieving that end will depend on its epistemological principles and categories being informed by time, space, and narrativity. ${ }^{119}$ 
Bringing the rich dimensions of ontological narrativity to the new identity approaches in social action theory is one way of doing this. The concepts of narrative identity and relational setting allow us to reconceptualize the subject-object dualism of modern social theory. They transform the dichotomy into numerous matrices of patterned relationships, social practices, and institutions mediated not by abstractions but by linkages of political power, social practices, and public narratives. This simultaneously reconceptualizes social agency away from its unitary status of individuation, and toward an understanding of agency constituted within institutions, structures of power, cultural networks, and, more generally, those others who are a central analytic dimension (again, not necessarily normative) of that identity. These conceptualizations are themselves premised on the extensive research, across time and space, which already suggests that social identities are constituted by the intricate interweaving of history, narrativity, social knowledge, and relationality, as well as institutional and cultural practices.

The narrative approach to identity thus addresses the incoherencies of theories of action that leave vast numbers of social actors and social practices thoroughly unaccounted for - redefined as "marginal," "deviant," or "anomalous." It also builds upon the strengths of the recent shift in sociologies of action from universal notions of agency to more particularistic identities - a shift that endows the previously marginalized with a powerful new sense of subjectivity. In recognizing the importance of these new sociologies of identity, however, I have also tried to call attention to their potential weaknesses - foremost among which are the tendencies to conflate analytic or structural relationality into normative values about "being-in-relations" (e.g., Chodorow and Gilligan), as well as the inadvertent ahistoricism that results from constructing categories of identity. ${ }^{120}$ There is, to be sure, an important theoretical distinction to be made between two kinds of categories those based on (1) taxonomical categories of identity aggregated from variables (age, sex, education, etc.) or "fixed" entities (woman, man, black) and, (2) categories that coincide with a narrative thematic. For instance, it is not hard to classify certain narratives as falling in the category of the "heroic Westerner," or "the virtues of American democracy." This is a classification, however, of the narrative itself. It can still be abstracted from context and its ontological relationality kept intact. By contrast, the classification of an actor divorced from analytic relationality is neither ontologically intelligible nor meaningful. In her study of audience responses to western movies, for instance, 
Shively appropriately must classify by theme the western movies she shows her audiences. ${ }^{121}$ Yet while these thematic classifications of the narratives remain stable throughout the study, her findings reveal that audience identification with and response to those themes depends less on the racial category of the respondent (native American or white) and more on the actors' changing social and historical embeddedness.

I am not suggesting that there is no place for the use of categories of identity in everyday social practice. ${ }^{122}$ Brint, for example, rightly says that the sociological use of categories reflects the "belief that the experience of common conditions of life ... makes people with shared attributes a meaningful feature of the social structure." ${ }^{123}$ But it is precisely because this belief is accepted into social analysis too uncritically that new theories of action centered around identity are often empirically confounded. There is no reason to assume a priori that people with similar attributes will share common experiences of social life, let alone be moved to common forms and meanings of social action, unless they share similar narrative identities and relational settings. Bringing narrativity to identity thus provides the conceptual sinews that produces a tighter, more historically sensitive coupling between social identity and agency.

\section{Acknowledgments}

Renee Anspach's, Rogers Brubaker's, and Arthur Stinchcombe's generosity of pen, insight, and spirit contributed mightily to my revisions on this article. Earlier versions were presented at the 1992 American Sociological Association Meetings, Pittsburgh; the Brenner Center for Comparative History and Social Theory, UCLA; and the Comparative Social Analysis Workshop, Department of Sociology, UCLA. I am grateful to the audiences in those settings for their spirited feedback, as well as to Craig Calhoun, Gloria Gibson, Elizabeth Long, Marc Steinberg, Mayer Zald, and the Editors of Theory and Society; to Jane Rafferty, for research assistance; and to Pat Preston, for heroic word processing. A different version of this article, co-authored with Gloria Gibson, will appear in Craig Calhoun, editor, Social Theory and the Constitution of Identity (Basil Blackwell, 1994). 


\section{Notes}

1. For some examples of the reinterpretation of female difference into a form of gender identity, see Nancy Chodorow, The Reproduction of Mothering (Berkeley: University of California Press, 1978); Jean Elshtain, Public Man, Private Woman: Women in Social and Political Thought (Princeton: Princeton University Press, 1981); Carol Gilligan, In a Different Voice: Psychological Theory and Women's Development (Cambridge: Harvard University Press, 1982); Catharine MacKinnon, Toward a Feminist Theory of State (Cambridge: Harvard University Press, 1989); Dorothy E. Smith, The Everyday World as Problematic: A Feminist Sociology (Boston: Northeastern University Press, 1987); Texts, Facts, and Femininity: Exploring the Relations of Ruling (London and New York: Routledge, 1990); and The Conceptual Practices of Power: A Feminist Sociology of Knowledge (Boston: Northeastern University Press, 1990); and Mary F. Belenky, Blythe M Clinchy, Nancy R. Goldberger, and Jill M. Tarule, Women's Ways of Knowing: The Development of Self, Voice, and Mind (New York: Basic Books, 1986). The criticism of categorical fixity is the animating impulse behind much of feminist, post-modernist, critical race theory, and the "new historicism." For contributions that have recently shown that racial and sexual categories cannot be conceived as pre-political or outside the bounds of social constitution, see Kathleen Canning, "Contesting the power of categories: Discourse, experience, and feminist resistance," Signs 19 (1994): 368-404; Roger Chartier, Cultural History: Between Practices and Representations, trans. Lydia G. Cochrane (Princeton: Princeton University Press, 1988); Patricia Hill Collins, Black Feminist Thought: Knowledge, Consciousness, and the Politics of Empowerment (Boston: Unwin Hyman, 1990); and "Transforming the inner circle: Dorothy Smith's challenge to sociological theory," Sociological Theory 10 (1992): 73-80; F. James Davis, Who is Black?: One Nation's Definition (Philadelphia: The Pennsylvania State University, 1991); Jane Flax, "Postmodernism and gender relations in feminist theory," in Linda Nicholson, editor, Feminism/Postmodernism (New York and London: Routledge: 1990), 39-62; and Thinking Fragments: Psychoanalysis, Feminism, and Postmodernism in the Contemporary West (Berkeley and Los Angeles: University of California Press, 1990); Nancy Fraser, Unruly Practices: Power, Discourse, and Gender in Contemporary Social Theory (Minneapolis: University of Minnesota Press, 1989); Donna Haraway, Simians, Cyborgs, and Women: The Reinvention of Nature (New York and London: Routledge, 1991); Thomas Laqueur, Making Sex: Body and Gender from the Greeks to Freud (Cambridge: Harvard University Press, 1990); Charles R. Lawrence, III, "The word and the river: Pedagogy and scholarship as struggle," Southern California Law Review 65/5 (1992): 22312298, Linda Nicholson, editor, Feminism/Postmodernism (New York: Routledge, 1990); Joan Wallach Scott, Gender and the Politics of History (New York: Columbia University Press, 1988); "On language, gender, and working-class history," in Gender and the Politics of History (New York: Columbia University Press, 1988), 53-67; and "The evidence of experience," Critical Inquiry 17/3 (1991): 773-797; Smith, The Everyday World as Problematic; Texts, Facts, and Femininity; and The Conceptual Practices of Power; Carol Tavris, The Mismeasure of Woman (New York: Simon \& Schuster, 1992); Patricia J. Williams, "On being the object of property," Signs 14/5 (1988): 5-24, and The Alchemy of Race and Rights: The Diary of a Law Professor (Cambridge: Harvard University Press, 1991).

2. Michael Carrithers, Steven Collins, and Steven Lukes, editors, The Category of the 
Person: Anthropology, Philosophy, History, trans. W. D. Halls (Cambridge: Cambridge University Press, 1985); Marcell Mauss, "A category of the human mind: The notion of person; the notion of self," in Carrithers, et al., editors, The Category of the Person, 1-25; Louis Dumont, Essays on Individualism (Chicago: University of Chicago Press, 1982).

3. Williams, The Alchemy of Race and Rights, 256-257 (italics mine).

4. This view of narrative as a representational methodology was importantly substantiated by the philosophers and historiographers. White and Mink both argued that despite the representational value of narrative, it had to be seen as a superimposed form that analysts/historians placed over the chaos of "reality" to organize it into coherency. See Hayden White, "The value of narrativity in the representation of reality," in W. J. T. Mitchell, editor, On Narrative (Chicago: University of Chicago Press, 1981), 1-23; "The question of narrative in contemporary historical theory," History and Theory 23 (1984): 1-33; and The Content of the Form (Baltimore: Johns Hopkins University Press, 1987); and Louis O. Mink, "The autonomy of historical understanding," in William H. Dray, editor, Philosophical Analysis and History (New York: Harper \& Row, 1966), 160-192; and "Narrative form as a cognitive instrument," in Ralph Cohen, editor, New Directions in Litera$r y$ History (Baltimore: The Johns Hopkins University Press, 1978), 107-124. See also Arthur C. Danto, Narration and Knowledge: Including the Integral Text of Analytical Philosophy of History (New York: Columbia University Press, 1985) for a complex philosophical discussion of the analytic place of narrative in historical analysis. The major exception to this position, and a major influence on the new narrative approach, is Paul Ricoeur, "The human experience of time and narrative," Research in Phenomenology 9/25 (1979): 17-34; "Narrative time," in W. J. T. Mitchell, editor, On Narrative (Chicago: University of Chicago Press, 1981), 165 186; and Time and Narrative, 2 vols., trans. Kathleen McLaughtin and David Pellauer (Chicago: University of Chicago Press, 1984-1986).

5. The journal Social Science History is representative of this trend.

6. See especially Ricoeur, "The human experience of time and narrative," and Time and Narrative. In law and critical race theory, see Williams, The Alchemy of Race and Rights; Lawrence, "The word and the river"; Clifford Geertz, "Local knowledge: Fact and law in comparative perspective," in Clifford Geertz, editor, Local Knowledge (New York: Basic Books, 1983); James Boyd White, When Words Lose Their Meaning: Constitutions and Reconstitutions of Language, Character, and Community (Chicago: University of Chicago Press, 1984); Ronald Dworkin, The Politics of Interpretation (Chicago: University of Chicago Press, 1982); in psychology, see Susan Hales, "The inadvertent rediscovery of self in social psychology," Journal for the Theory of Social Behavior 15 (October 1985): 237-282; Susan Kemper, "The development of narrative skills: Explanations and entertainments," in Stan A. Kuczaj, II, editor, Discourse Development: Progress in Cognitive Development Research (New York: Springer-Verlag, 1984), 99-124; Jerome Bruner, Actual Minds, Possible Worlds (Cambridge: Harvard University Press, 1986); and "Life as narrative," Social Research 54/1 (1987): 11-32; Theodore R. Sarbin, editor, Narrative Psychology: The Storied Nature of Human Conduct (New York: Praeger, 1986); Kenneth J. Gergen and Mary M. Gergen, "Narrative form and the construction of psychological science," in Theodore R. Sarbin, editor, Narrative Psychology: The Storied Nature of Human Conduct (New York: Praeger, 1986), 22-44; in medicine, see Gareth Williams, "The genesis of chronic illness: Narrative reconstruction," Sociology of Health and Illness 6 (1984): 175- 
200; Arthur Kleinman, The Illness Narratives (New York: Basic, 1988); in psychoanalytic theory, see Donald P. Spence, Narrative Truth and Historical Truth: Meaning and Interpretation in Psychoanalysis (New York: W. W. Norton, 1982); Roy Schafer, "Narration in the psychoanalytical dialogue," in W. J. T. Mitchell, editor, On Narrative (Chicago: University of Chicago Press, 1981), 2549; and The Analytic Attitude (New York: Basic Books, 1983); in education, see Carol Whitherell and Nel Noddings, editors, Stories Lives Tell: Narrative and Dialogue in Education (New York: Teachers College Press, 1991); in philosophy, see Alasdair MacIntyre, After Virtue: A Study in Moral Theory (Notre Dame: University of Notre Dame Press, 1981); Charles Taylor, Sources of the Self (Cambridge: Harvard University Press, 1989); in gender studies, see Patrizia Violi, "Gender, subjectivity and language," in Gisela Bock and Susan James, editors, Beyond Equality and Difference: Citizenship, Feminist Politics and Female Subjectivity (New York and London: Routledge, 1992), 164-176; Linda M. G. Zerilli, "Rememoration or war? French feminist narrative and the politics of self-representation," Differences 3/1 (1991): 1-19; Susan Groag Bell and Marilyn Yalom, editors, Revealing Lives: Autobiography, Biography, and Gender (Albany: State University of New York Press, 1990); Nancy K. Miller, Getting Personal: Feminist Occasions and Other Autobiographical Acts (New York: Routledge, 1991); Personal Narratives Group, editor, Interpreting Women's Lives: Feminist Theory and Personal Narratives (Bloomington: University of Indiana Press, 1989); Mary Jo Maynes, "Gender and narrative form in French and German working-class autobiographies," in Personal Narratives Group, editor, Interpreting Women's Lives: Feminist Theory and Personal Narratives (Bloomington: University of Indiana Press, 1989), 103-117; Linda Gordon, "What's new in women's history," in Teresa de Lauretis, editor, Feminist Studies/Critical Studies (Bloomington: Indiana University Press, 1986), 20-38; Elspeth Graham, Hilary Hinds, Elaine Hobby, and Helen Wilcox, editors, Her Own Life: Autobiographical Writings by Seventeenth-Century Englishwomen (London: Routledge, 1989); in anthropology, see E. Valentine Daniel, Fluid Signs: Being a Person the Tamil Way (Berkeley: University of California Press, 1984); Victor W. Turner and Edward M. Bruner, editors, The Anthropology of Experience (Urbana: University of Illinois Press, 1986); Sherry Ortner, "Narrativity in history, culture, and lives," CSST Working Paper \#66 (Ann Arbor: University of Michigan, 1991); in physics, Nancy Cartwright, How the Laws of Physics Lie (Oxford: Clarendon Press, 1983); Stephen Jay Gould, "Mighty Manchester," New York Review of Books (27 October 1988); and Wonderful Life: The Burgess Shale and the Nature of History (New York and London: W. W. Norton \& Co., 1989).

7. Cf. especially the "life stories" scholarship of Daniel Bertaux, Biography and Society (Beverly Hills: Sage, 1981); Daniel Bertaux and Martin Kohli, "The life story approach: A continental view," Annual Review of Sociology 10 (1984): 215237; Mark Freeman, "History, narrative, and life-span developmental knowledge," Human Development 27 (1984): 1-19; Charlotte Linde, "Private stories in public discourse: Narrative analysis in the social sciences," Poetics 15 (1986): 183-202; and Livia Polanyi, Telling the American Story (Norwood, N.J.: Ablex Publishing, 1985).

8. Margaret R. Somers, "Narrativity, narrative identity, and social action: Rethinking English working-class formation," Social Science History 16/4 (1992): 591-630.

9. Attention to identity-formation is slowly gaining ground in sociology. Significantly, the two major sources for these developments are both groups of "outsiders" 
from the discipline who have been until recently marginal to the theorized social actor: 1) women, people of color, ethnic minorities, and more recently, those who feel nationally excluded, see, e.g., Judith Butler and Joan Scott, editors, Feminists Theorize the Political (New York: Routledge, 1992); Collins, Black Feminist Thought; Barbara Laslett, "Thinking about the subject," Newsletter of the Comparative and Historical Sociology Section of the American Sociological Association 5 (1992); Smith, The Everyday World as Problematic; Texts, Facts, and Femininity, and The Conceptual Practices of Power, and Anna Yeatman, "A feminist theory of social differentiation," in Linda J. Nicholson, editor, Feminism/Postmodernism (New York and London: Routledge, 1990), 281-299; and 2) the "new social movements" in Europe and America whose goals of "identity-expression" have been used to distinguish them from more "instrumental" movements, e.g., Stanley Aronowitz, The Politics of Identity: Class, Culture, Social Movements (New York: Routledge, Chapman and Hall, Inc., 1992); Craig J. Calhoun, "Imagined communities and indirect relationships: Large-scale social integration and the transformation of everyday life," in Pierre Bourdieu and James S. Coleman, editors, Social Theory for a Changing Society (Boulder, Col.: Westview Press and New York: Russell Sage Foundation, 1991), 95-120; "Morality, identity, and historical explanation: Charles Taylor on the sources of the self," Sociological Theory 9/2 (1991) 232-263; and "The problem of identity in collective action," in MacroMicro Linkages in Sociology (Beverly Hills, Calif.: Sage, 1991), 51-75; Jean L. Cohen, Strategy or identity: New theoretical paradigms and contemporary social movements," Social Research 52 (1985): 663-716; Jean L. Cohen and Andrew Arato, Civil Society and Political Theory (Cambridge: The MIT Press, 1992); Alberto Melucci, Nomads of the Present: Social Movements and Individual Needs in Contemporary Society (Philadelphia: Temple University Press, 1989); Alessandro Pizzorno, "On the rationality of democratic choice," Telos 63 (1985): 4169; and Alain Touraine, "An introduction to the study of social movements," Social Research 52/4 (1985): 749-787.

10. Aronowitz, The Politics of Identity, 12.

11. Alessandro Pizzorno, "Political exchange and collective identity in industrial conflict," in C. Crouch and A. Pizzorno, editors, The Resurgence of Class Conflict in Western Europe Since 1968 (London: Macmillan, 1978), 277-298; and "On the rationality of democratic choice."

12. Chodorow, The Reproduction of Mothering; Elshtain, Public Man, Private Woman.

13. Chodorow, ibid.; and Gilligan, In a Different Voice.

14. See also Elshtain, Public Man, Private Woman, MacKinnon, Toward a Feminist Theory of State, and Sara Ruddick, Maternal Thinking: Toward a Politics of Peace (New York: Ballantine Books, 1989) for extremely influential versions of feminist identity politics. For an extremely important discussion of these issues, see Seyla Benhabib, "The generalized and the concrete other: The Kohlberg-Gilligan controversy and feminist theory," in Seyla Benhabib and Drucilla Cornell, editors, Feminism as Critique (Minneapolis: University of Minnesota Press, 1987), 77-95.

15. MacKinnon, Toward a Feminist Theory of State.

16. Molefi Kete Asante, The Afrocentric Idea (Philadelphia: Temple University Press, 1987), 165.

17. Ibid.

18. Christine Di Stefano, "Dilemmas of difference: Feminism, modernity, and postmodernism," in Linda J. Nicholson, editor, Feminism/Postmodernism (New York and London: Routledge, 1990), 63-82. 
19. Collins, Black Feminist Thought; bell hooks, From Margin to Center (Boston: South End Press, 1984); June Jordan, Civil Wars (Boston: Beacon, 1981); Audre Lorde, Sister Outsider (Trumansberg, N.Y.: The Crossing Press, 1984).

20. Scott, Gender and the Politics of History.

21. Ibid.; see also Denise Riley, Am I That Name? Ferninism and the Category of "Women" in History (Minneapolis: University of Minnesota Press, 1988).

22. Joan W. Scott, "Experience," in Judith Butler and Joan Scott, editors, Feminists Theorize the Political (New York: Routledge, 1992), 22-40.

23. Haraway, Simians, Cyborgs, and Women.

24. Melucci, Nomads of the Present.

25. These criticisms of identity-theories are articulated in many different ways and places. Some of the most important include Butler and Scott, Feminists Theorize the Political; Canning, "Contesting the power of categories"; Flax, "Postmodernism and gender relations," and Thinking Fragments; Nancy Fraser and Linda J. Nicholson, "Social criticism without philosophy: An encounter between feminism and postmodernism," in Linda J. Nicholson, editor, Feminism/Postmodernism (New York and London: Routledge, 1990), 19-38; Haraway, Simians, Cyborgs, and Women; Charles Lemert, "Subjectivity's limit: The unsolved riddle of the standpoint," Sociological Theory (1992) 63-72; Denise Riley, Am I That Name?; Scott, Gender and the Politics of History, and "Experience."

26. See especially Seyla Benhabib, Situating the Self: Gender, Community, and Postmodernism (Cambridge: Polity, 1992), and Scott, Gender and the Politics of History, "The evidence of experience," and "Experience"; Canning, "Contesting the power of categories"; Mary Poovey, Uneven Developments (Chicago: University of Chicago Press, 1988); Martha Minow, Making All the Difference: Inclusion, Exclusion, and American Law (Ithaca: Cornell University Press, 1990); Regenia Gagnier, Subjectivities: A History of Self-Representation in Britain, 1832-1920 (New York: Oxford University Press, 1991); and Cohen and Arato, Civil Society and Political Theory are but a few.

27. Fraser and Nicholson, "Social criticism without philosophy," 34.

28. Discussion of collective projects in the establishment of professional identity include Magali Sarfatti Larson, The Rise of Professionalism: A Sociological Analysis (Berkeley: University of California Press, 1977), and Andrew Abbott, The System of Professions: An Essay on the Division of Expert Labor (Chicago: University of Chicago Press, 1988). For the social sciences in particular, see Mayer Zald, "Sociology as a discipline: Quasi-science and quasi-humanities,". The American Sociologist 22/3,4 (1991): 165-187; Stefan Collini, Donald Winch, and J. W. Burrow, editors, That Noble Science of Politics: A Study in Nineteenth Century Intellectual History (Cambridge: Cambridge University Press, 1983); Ian Hacking, The Taming of Chance (Cambridge: Cambridge University Press, 1990); and Dorothy Ross, The Origin of American Social Science (New York: Cambridge University Press, 1991).

29. Abell and Abbott have been in the vanguard of challenging this exclusion in the domain of methodology. See Peter Abell, "Comparative narratives," Journal for the Theory of Social Behavior 14 (1984): 309-331; and The Syntax of Social Life (Oxford: Oxford University Press, 1987); Andrew Abbott, "Sequences of social events," Historical Methods 16 (1983): 129-147; "Event sequence and event duration," Historical Methods 17 (1984): 192-204; "Transcending general linear reality," Sociological Theory 6 (1988) 169-186; "Conceptions of time and events in social science methods: Causal and narrative approaches," Historical Methods 
23 (1990): 140-150; and "From causes to events: Notes on narrative positivism," Sociological Methods \& Research 20/4 (1992): 428-455. Christopher Lloyd, Explanation in Social History (New York: Basil Blackwell, 1986), provides an excellent analysis of the development of these binary oppositions in the social sciences. A recent example of defining sociology by its opposition to writing "mere" history can be found in Edgar Kiser and Michael Hechter, "The role of general theory in comparative-historical sociology," American Journal of Sociology 97 (1991): 1-30.

30. The term comes from and is elaborated in Margaret R. Somers, "Where is sociology after the historic turn? Knowledge cultures and historical epistemologies," in Terrence J. McDonald, editor, The Historic Turn in the Human Sciences (Ann Arbor: University of Michigan Press, forthcoming).

31. On historians abandoning traditional notions of narrative or even standard notions of history per se, see e.g., Alan Megill, "Recounting the past: 'Description' explanation, and narrative in historiography," American Historical Review 94/3 (1989): 627-653; and "Fragmentation and the future of historiography," American Historical Review 96 (June 1991): 693-698; Peter Novick, That Noble Dream: The 'Objectivity Question' and the American Historical Profession (Cambridge: Cambridge University Press, 1988); and "My correct views on everything," American Historical Review 96 (1991): 699-703; John E. Toews, "Intellectual history after the linguistic turn: The autonomy of meaning and the irreducibility of experience," American Historical Review 92/4 (1987): 879-907; Geoff Eley, "Is all the world a text? From sociological history to the history of society two decades later," in Terrence J. McDonald, editor, The Historic Turn in the Human Sciences (Ann Arbor: University of Michigan Press, forthcoming); and Lawrence Stone, "The revival of narrative: Reflections on an old new history," Past and Present 85 (1979): 3-25.

32. Louis O. Mink, "The autonomy of historical understanding," in William H. Dray, editor, Philosophical Analysis and History (New York: Harper \& Row, 1966), 160-192; White, "The question of narrative."

33. See note 6 above.

34. This is beginning to change, e.g., Jeffrey C. Alexander, Structure and Meaning: Rethinking Classical Sociology (New York: Columbia University Press, 1989); Janet Hart, "Cracking the code: Allegory and political mobilization in the Greek resistance," Social Science History 16/4 (1992): 631-668; William H. Sewell, Jr., "Introduction: Narratives and social identities," Social Science History '16/3 (1992): 479-488; Somers, "Narrativity, narrative identity, and social action"; George Steinmetz, "Reflections on the role of social narratives in working-class formation: Narrative theory in the social sciences," Social Science History 16/3 (1992): 489-516; Harrison C. White, Identity and Control: A Structural Theory of Social Action (Princeton, N.J.: Princeton University Press, 1992). Harrison White's Identity and Control has broken critical ground by bringing narrativity (stories) into the heart of his structural theory of social action; and see also Peter Bearman, "The social structure of suicide," Sociological Forum 5 (September 1991): 501-524. Jeffrey Alexander has also theorized the importance of narrative to theories of social action in J. C. Alexander and P. Smith, "The discourse of civil society: A new proposal for cultural studies," Theory and Society 22 (1993): 151207, and Jeffrey C. Alexander, "Modern, anti, post, neo: How social theories have tried to understand the 'new world' of 'our time," "unpublished manuscript, 1993. For additional discussion, see Philip Abrams, Historical Sociology (Ithaca: Cornell University Press, 1982). 
35. See, for example, Jeffrey C. Alexander, Positivism, Presuppositions, and Current Controversies, Vol. 1 of Theoretical Logic in Sociology (Berkeley and Los Angeles: University of California Press, 1982), Action and Its Environment: Towards a New Synthesis (New York: Columbia University Press, 1988), and Structure and Meaning; Pierre Bourdieu, An Outline of a Theory of Practice, trans. by Richard Nice (New York: Cambridge University Press, 1977); and The Logic of Practice (Stanford: Stanford University Press, 1990), James Coleman, Foundations of Social Theory (Cambridge: Harvard University Press, 1990); Anthony Giddens, "The 'individual' in writings of Emile Durkheim," in Studies in Social and Political Theory (New York: Basic Books Inc., 1977); and The Constitution of Society: Outline of the Theory of Structuration (Cambridge: Polity Press, Berkeley: University of California Press, 1985); Jürgen Habermas, Communication and the Evolution of Society (Boston: Beacon Press, 1979); and Theory of Communicative Action, Vol. I: Reason and the Rationalization of Society, trans. Thomas McCarthy (Boston: Beacon Press, 1984); Geoffrey Hawthorne, Enlightenment and Despair (London: Cambridge University Press, 1976); William H. Sewell, Jr., "Theory of action, dialectics and history: Comment on Coleman," American Journal of Sociology 43 (1986): 166-172; Smith, The Everyday World as Problematic; Texts, Facts, and Femininity; and The Conceptual Practices of Power; White, Identity and Control.

36. Steven Seidman, "The end of sociological theory: The postmodern hope," Sociological Theory 9/2 (1991): 131-146.

37. And despite their radically divergent evaluation of what counts as theory, the same conceptual polarities between narrative and causality are posited in the work of Abbott, "Conceptions of time and events in social science methods" and "from causes to events," on the one hand, and Kiser and Hechter, "The role of general theory," on the other.

38. William E. Connolly, "The irony of interpretation," in D. Conway and John Seery, editors, The Politics of Irony (New York: St. Martin's Press), 119-150.

39. This and the context of discovery were first formalized by Hans Reichenbach in Elements of Symbolic Logic (New York: Macmillan, 1947). For discussion, see Somers, "Where is sociology after the historic turn?"

40. In his "Introduction" to the special section on "Narrative Analysis in Social Science," Sewell stresses this point in observing the highly unusual "departure [of the topic] from the usual fare of Social Science History and from the vision of socialscientifically informed historical study that has dominated the SSHA since its founding a decade and a half ago" (479).

41. See especially Mauss, "A category of the human mind," and, more generally, the essays collected in Carrithers, et al., editors, The Category of the Person.

42. For discussion of the new identity-politics in theories of social movements, see note 9 .

43. This discussion of narrative in the next few paragraphs draws from Somers, "Narrativity, narrative identity, and social action." For a range of discussions of narrative theory, see Robert Scholes and Robert Kellogg, The Nature of Narrative (London: Oxford University Press, 1966); Gerard Genette, Narrative Discourse: An Essay in Method, trans. Jane E. Lewin (Ithaca: Cornell University Press, 1980); W. J. T. Mitchell, editor, On Narrative (Chicago: University of Chicago Press, 1981); Fredric Jameson, The Political Unconscious. Narrative as a Socially Symbolic Act (Ithaca: Cornell University Press, 1981); Peter Brooks, Reading for the Plot: Design and Intention in Narrative (New York: Alfred A. Knopf, 1984); 
Roland Barthes, "Introduction to the structural analysis of the narrative," trans. Richard Miller, Occasional Paper, Centre for Contemporary Cultural Studies, University of Birmingham, published in Image-Music-Text, trans. Stephen Heath (New York: Hill and Wang, 1974 (1966)).

44. I am happy with Friedland and Alford's definition of an institution as: "simultaneously material and ideal, systems of signs and symbols, rational and transrational ... supraorganizational patterns of human activity by which individuals and organizations produce and reproduce their material subsistence and organize time and space ... [t]hey are also symbolic systems, ways of ordering reality, and thereby rendering experience of time and space meaningful." Roger Freidland and Robert R. Alford, "Bringing society back in: Symbols, practices, and institutional contradictions," in Walter W. Powell and Paul J. DiMaggio, editors, The New Institutionalism in Organizational Analysis (Chicago: University of Chicago Press, 1991), 243.

45. Paul Veyne, Writing History: Essay of Epistemology, trans. Mina Moore-Rinvolucri (Middletown, Conn.: Wesleyan University Press, 1984 (1971)); Ricoeur, "Narrative time," and Time and Narrative.

46. This is indeed a different approach to the concept of explanation that the strictest of analytic philosophers of science would accept - causality as a deductive instance of a generalization. Indeed the very strength and utility of the latter is its valid "denarrativization" or abstraction of instances, elements, or events from time and space into categories. See Somers, "Where is sociology after the historic turn?"

47. Donald Polkinghorne, Narrative Knowing and the Human Sciences (Albany: SUNY Press, 1988), 21.

48. MacIntyre's discussion in After Virtue of narrative, practices, and the self was the first and most significant influence on my historical conceptualization of narrative identity. See Margaret R. Somers, The People and the Law: Narrative Identity and the Place of the Public Sphere in the Formation of English Working Class Politics 1300-1850, a Comparative Analysis (Ph.D. Dissertation, Harvard University, 1986).

49. Ricoeur, "The human experience of time and narrative"; Veyne, Writing History; Polkinghorne, Narrative Knowing and the Human Sciences.

50. White, The Content of the Form.

51. Linde, "Private stories in public discourse"; Polanyi, Telling the American Story.

52. Taylor, Sources of the Self. Also see Calhoun, "Morality, identity, and historical explanation."

53. Somers, The People and the Law.

54. Bruner, Actual Minds, Possible Worlds; Frank Kermode, "Secrets and narrative sequence," in W. J. T. Mitchell, editor, On Narrative (Chicago: University of Chicago Press, 1981).

55. For an especially useful empirical application, see Alexander, Structure and Meaning, for the impressive array of narratives that were deployed to explain action on both sides during the Watergate hearings.

56. This is not to endorse the hermeneutic claim that the actor's intentions or selfunderstanding is a sufficient condition for a sociological understanding of action.

57. Taylor, Sources of the Self, 51-5122. Samples of different approaches to ontological narratives can be found in Sarbin, Narrative Psychology; MacIntyre, After Virtue; Taylor, Sources of the Self, Bruner, "Life as narrative"; Bell and Yalom, Revealing Lives; Bertaux and Kohli, "The life story approach"; Stephen Crites, "Storytime: Recollecting the past and projecting the future," in Theodore R. 
Sarbin, editor, Narrative Psychology: The Storied Nature of Human Conduct (New York: Praeger, 1986), 152-173; John Ferccero, "Autobiography and narrative," in Thomas C. Heller, Morton Sosna, and David E. Wellbery, editors, Reconstructing Individualism: Autonomy, Individuality, and the Self in Western Thought (Stanford, Calif.: Stanford University Press, 1986), 16-29; Freeman, "History, narrative"; Kenneth J. Gergen, "Social psychology as history," Journal of Personality and Social Psychology 26 (1973): 309-320; "Stability, change, and chance in understanding human development," in Nancy Datan and Wayne W. Reese, editors, Life-Span Development Psychology: Dialectical Perspectives in Experimental Research (New York: Academic Press, 1977), 135-158; and "The social constructionist movement in modern psychology," American Psychologist 40 (1985): 266-275; Gergen and Gergen, "Narrative form"; Joan Didion, After Henry (New York: Simon \& Schuster, 1992); Graham Swift, Waterland (New York: Washington Square Press, 1983).

58. Alexander Nehamas, Nietzsche: Life as Literature (Cambridge: Harvard University Press, 1985).

59. David Carr, "Life and the narrator's art," in Hugh J. Silverman and Don Idhe, editors, Hermeneutics and Deconstruction (Albany: State University of New York Press, 1985), 108-121; and "Narrative and the real world," History and Theory 25 (1986): 117-131.

60. Sarbin, Narrative Psychology; Personal Narratives Group, Interpreting Women's Lives.

61. Taylor, Sources of the Self, MacIntyre, After Virtue.

62. Organizational theory is one area of the social sciences that has used the narrative concept in particularly creative ways. Cf. Paul DiMaggio, "Interest and agency in institutional theory," in Lynn G. Zucker, editor, Institutional Patterns and Organization: Culture and Environment (Cambridge, Mass.: Ballinger, 1988), 3-22; Joanne Martin, Martha S. Feldman, Mary Jo Hatch, and Sim B. Sim, "The uniqueness paradox in organizational stories," Administrative Science Quarterly 38 (1983): 438-453; John W. Meyer and Brian Rowan, "Institutionalized organizations: Formal structure as myth and ceremony," American Journal of Sociology 83 (1977): 340-363; John W. Meyer and W. Richard Scott, Organizational Environments: Ritual and Rationality (Beverly Hills, Calif.: Sage, 1983); Ian Mitroff and R.H. Killman, "Stories managers tell: A new tool for organization problem solving," Management Review 64 (1975): 18-28; Linda Smircich, "Concepts of culture and organizational analysis," Administrative Science Quarterly 28 (1983): 339-358; Lynn G. Zucker, "The role of institutionalization in cultural persistence," in Walter W. Powell and Paul J. DiMaggio, editors, The New Institutionalism in Organizational Analysis (Chicago: University of Chicago Press, 1991), 83107.

63. Taylor, Sources of the Self, 39.

64. Jameson, The Political Unconscious; J. F. Lyotard, The Post-Modern Condition: A Report on Knowledge (Minneapolis: University of Minnesota Press, 1984); Michel Foucault, An Archaeology of Knowledge, trans. Alan Sheridan (New York: Pantheon, 1972); and The Order of Things: An Archaeology of the Human Sciences (New York: Vintage, 1973 (1970)).

65. See especially Alexander, "Modern, anti, post, neo."

66. On narrative methodology in historical sociology, see note 3; cf. Abell, "Comparative narratives," and The Syntax of Social Life; Abbott, "Conceptions of time and events," and "From causes to events"; Richard Harvey Brown, "Positivism, 
relativism, and narrative in the logic of the historical sciences," American Historical Review 92/4 (1987): 908-920; and "Rhetoric, textuality, and the postmodern turn in sociological theory," Sociological Theory 8/2 (1990): 188-197; Larry W. Isaac and Larry J. Griffin, "Ahistoricism in time-series analyses of historical processes," American Sociological Review 54 (1989): 873-890; Larry J. Griffin, "Narrative, event structure analysis, and causal interpretation in historical sociology," American Journal of Sociology 98/5 (1993): 1094-1133; Jill Quadagno and Stan J. Knapp, "Have historical sociologists forsaken theory?: Thoughts on the history/theory relationship," Sociological Methods and Research 20/4 (1992): 481-507; John Shelton Reed, "On narrative and sociology," Social Forces 68/I (1989): 1-14, William H. Sewell, Jr., "Three temporalities: Toward a sociology of the event," in Terrence J. McDonald, editor, The Historic Turn in the Human Sciences (Ann Arbor: University of Michigan Press, forthcoming); Somers, "Where is sociology after the historic turn?" Although they do not use the term "narrative" explicitly, Arthur Stinchcombe, in Theoretical Methods in Social History (New York: Academic Press, 1978), and Charles Tilly, in "To explain political processes," Center for Studies of Social Change Working Paper \# 168 (New York: New School for Social Research, 1993), both develop important sequential and temporally-sensitive historical methodologies.

67. The major historical sociological exceptions outside of gender studies are Charles Tilly, Big Structures, Large Processes, Huge Comparisons (New York: Russell Sage Foundation, 1984); Immanuel Wallerstein, Unthinking Social Science (Cambridge: Polity Press, 1991); and White, Identity and Control.

68. We are faced with an even greater problem in thinking about explanatory sociological narrative. Indeed in light of their status as the epistemological other, constructing narratives as explanations would seem to be precisely what we as social scientists do not want to do. Of course, this raises the question of what counts as an explanation; there are, after all, competing positions on the validity capacity of different modes of justification. Rather than argue the nature of and case for explanatory narrativity that has been done elsewhere and at some length, e.g., Abell, "Comparative narratives," and The Syntax of Social Life; Abbott, "Conceptions of time and events," and "From causes to events"; Ron Aminzade, "Historical sociology and time," Sociological Methods and Research 20/4 (1992): 456480; Quadagno and Knapp, "Have historical sociologists forsaken theory?"; and Somers, "Where is sociology after the historic turn?", I simply argue that to say that sociological explanations entail analytic narrativity is not the same as arguing that social science theory is solely narrative. As Alexander recently argued, it is also a code. See Jeffrey C. Alexander, "Sociological theory and the claim to reason: Why the end is not in sight," Sociological Theory 9/2 (1991): 147-153, 149; Basil Bernstein, Class, Codes, and Control (New York: Schocken, 1971). Even more important, to argue the case for explanatory narrativity is not to argue that there is no qualitative difference between at least the norms of analytic narrativity on the one hand, and those of cultural and ontological narrativity, on the other. The latter gain meaning through internal integrity alone, that is, they are only partially subjected to external truth criteria. Alexander ("Sociological theory," 149) also reminds us "science differs from other narratives because it commits the success of its story to the criterion of truth. For every scientific narrative we are compelled to ask, 'Do we know whether it is true?" The strength of explanatory narrativity, however, is that it steps out of the typically "either/or" version of "truth" versus "relativism" and uses criteria for validity that are outside the ex- 
tremes of "localism" versus foundational truth. Narrative explanatory analysis, from this perspective, guides us to construct and to believe in "the best possible account" at the same time that we know full well that (1) what counts as "best" is itself historical and (2) that these criteria will change and change again. See Helen Longino, Science as Social Knowledge (Princeton: Princeton University Press, 1990); Alasdair MacIntyre, "The essential contestability of some social concepts," Ethics 1 (1973): 1-9; and "Epistemological crises, dramatic narrative, and the philosophy of science," in Gary Gutting, editor, Paradigms and Revolutions (Notre Dame: University of Notre Dame Press, 1980), 54-74; Nehamas, Nietzsche; and Charles Taylor, "Overcoming epistemology," in Kenneth Baynes, James Bohman, and Thomas McCarthy, editors, After Philosophy: End or Transformation? (Cambridge: The MIT Press, 1991), 464-488.

69. E.g., White, Identity and Control; Taylor, Sources of the Self, Cohen, "Strategy or identity."

70. Harrison C. White, Scott A. Boorman, and Ronald L. Breiger, "Social structure from multiple networks I: Blockmodels of roles and positions," American Journal of Sociology 81/4 (1976): 730-780; White, Identity and Control. Thus, it is not at all surprising that White has made stories and identity central aspects of his theory of social action. An excellent presentation of the structural approach is offered by B. Wellman and S. D. Berkowitz, "Introduction: Studying social structures," in Wellman and Berkowitz, editors, Social Structures: A Network Approach (Cambridge: Cambridge University Press, 1988), 15: “...mainstream sociologists have tended to think in terms of categories of social actors who share similar characteristics: "women," "the elderly," "blue-collar workers," "emerging nations," and so on ... this kind of approach has its uses, but it has misled many sociologists into studying the attributes of aggregated sets of individuals rather than the structural nature of social systems." See also B. Wellman, "Structural analysis: From method and metaphor to theory and substance," in Wellman and Berkowitz, Social Structures, 19-61.

71. Even an isolated "hermit" is a social actor and must thus be made intelligible through a relational and narrative approach.

72. See Craig J. Calhoun, "Community: Toward a variable conceptualization for comparative research," Social History 5 (1980): 105-129, for a similar argument about the use of "community" as a variable rather than an ideal type.

73. Carolyn Steedman, Landscape for a Good Woman: A Story of Two Lives (New Brunswick, N.J.: Rutgers University Press, 1987).

74. Richard Hoggart, The Uses of Literacy (Harmondsworth: Penguin, 1959); Jeremy Seabrook, Working Class Childhood (London: Gollancz, 1982).

75. All of Steedman's writings could be seen as implicit elaborations on the theme of narrative identity. See Carolyn Steedman, Landscape for a Good Woman; The Radical Soldier's Tale: John Pearman, 1819-1908 (London and New York: Routledge, 1988); Childhood, Culture, and Class in Britain: Margaret McMillan, 18601931 (New Brunswick, N.J.: Rutgers University Press, 1990); Past Tenses: Essays on Writing, Autobiography and History (London: Rivers Oram Press, 1992).

76. Davis, Who is Black?

77. Ibid., 174.

78. Somers, "Narrativity, narrative identity, and social action."

79. T. H. Marshall, "Citizenship and social class," in Class, Citizenship and Social Development: Essays by T. H. Marshall (New York: Doubleday, 1964 (1949)), 65-123. 
80. Calhoun, in "The problem of identity," gives an example of how identity-politics moved Chinese students in Tienanmen Square to take risks with their lives that cannot be accounted for in rational or value terms.

81. Ibid.

82. Fantasia's study of varying cultures of solidarity is one of the best examples of the empirical power of the narrative identity approach over the interest-based one. See Rick Fantasia, Cultures of Solidarity (Berkeley and Los Angeles: University of California Press, 1988).

83. Michael Mann, "The origins of social power," A History of Power from the Beginning to A.D. 1760, Vol. 1 (Cambridge: Cambridge University Press, 1986). Tilly says "society is a thing apart" is the first of his famous "eight pernicious postulates"; see Tilly, Big Structures; White, Identity and Control.

84. See also Pierre Bourdieu, "Social space and the genesis of groups," Theory and Society 14 (1985): 723-744.

85. On the epistemological significance of networks and relational analysis over categories in understanding social structures see Tilly, Big Structures; White, Boorman, and Breiger, "Social structure from multiple networks"; and White, Identity and Control; for applications in historical sociology, see Roger V. Gould, "Multiple networks and mobilization in the Paris Commune, 1871," American Sociological Review 56/6 (1991): 716-728; Mann, "The origins of social power"; and Peter Bearman, Relations into Rhetorics (New Brunswick, N.J.: Rutgers University Press, 1993).

86. MacIntyre, After Virtue.

87. Important views of the value of theoretically disaggregating social reality can be found in Daniel Bell, "The disjuncture of realms," in The Cultural Contradictions of Capitalism (New York: Basic Books, 1976); and Michael Walzer, Spheres of Justice (New York: Basic Books, 1982).

88. See e.g. Pizzorno, "Political exchange and collective identity," and "On the rationality of democratic choice"; Melucci, Nomads of the Present.

89. This is elaborated in Jeffrey C. Alexander, The Classical Attempt at Theoretical Synthesis: Max Weber, Vol. 3 of Theoretical Logic in Sociology (Berkeley and Los Angeles: University of California Press, 1983).

90. Cohen and Arato challenge this point effectively in Civil Society and Political Theory.

91. On the concept of provisioning, see Marshall Sahlins, Culture and Practical Reason (Chicago: University of Chicago Press, 1976). And for the importance of provisioning for gender analysis, see Nancy Fraser and Linda Gordon, "Contrast versus charity, participation and provision: A reconsideration of social citizenship," unpublished paper (Ann Arbor: The University of Michigan, 1992).

92. Patrick Joyce, editor, The Historical Meanings of Work (Cambridge: Cambridge University Press, 1987). For the most empirically-based sociological demonstration of the culturally-laden nature of the economy, see Viviana Zelizer, Pricing the Priceless Child: The Changing Social Value of Children (New York: Basic Books, 1985); and "Beyond the polemics of the market: Establishing a theoretical and empirical agenda," Sociological Forum 3 (1987): 614-634.

93. See also Patrick Joyce, Visions of the People: Industrial England and the Question of Class, 1848-1941 (Cambridge: Cambridge University Press, 1991); William M. Reddy, Money and Liberty in Modern Europe: A Critique of Historical Understanding (Cambridge: Cambridge University Press, 1987); Michael Sonenscher, "Mythical work: Workshop production and the Compagnonnages of eighteenth- 
century France," in Patrick Joyce, editor, The Historical Meanings of Work (Cambridge: Cambridge University Press, 1987).

94. Neil Smelser, Social Change in the Industrial Revolution (Chicago: University of Chicago Press, 1959).

95. Somers, "Property, law, and the public sphere in the formation of modern citizenship rights," in John Brewer, editor, Early Modern Conceptions of Property (Berkeley: University of California Press, forthcoming).

96. Carol B. Stack, All Our Kin (New York: Harper and Row, 1974); Maxine Berg, "Women's work, mechanisation and the early phases of industrialisation in England," in Patrick Joyce, The Historical Meanings of Work (Cambridge: Cambridge University Press, 1987), 64-98; Karl Polanyi, The Livelihood of Man, ed. Harry W. Pearson (New York: Academic Press, 1977).

97. Touraine, "An introduction to the study of social movements"; Cohen, "Strategy of identity"; Cohen and Arato, Civil Society.

98. See Frank Parkin, Marxism and Class Theory: A Bourgeois Critique (New York: Columbia University Press, 1979), for a sociological elaboration of this basic Weberian and anthropological notion.

99. See, e.g., Stack, All Our Kin; David Vincent, Bread, Knowledge and Freedom: A Study of Nineteenth-Century Working Class Autobiography (London: Europa Publications, 1981); Louise Tilly, J. W. Scott, and M. Cohen, "Women's work and European fertility patterns," Journal of Interdisciplinary History 6 (1976): 447476.

100. MacIntyre, After Virtue, 26.

101. Cited in E. P. Thompson, "The moral economy of the English crowd," Past and Present 50 (1971): 77-136.

102. Ortner calls this "rupturing of narrativity" in her analysis of Eliot Liebow's Tally's Comer where she gives an example of how power relations have ruptured the narrative identities - and thus "normal future-oriented" behavior - or urban AfricanAmerican men (Ortner, "Narrativity in history"). See also Haraway, Simians, Cyborgs, and Women, and Lemert, "Subjectivity's limit" on "fractured identities."

103. Violi, "Gender, subjectivity and language."

104. Ibid,., 175.

105. Steedman, Landscape for a Good Woman.

106. Collins, Black Feminist Thought.

107. Williams, The Alchemy of Race and Rights, 6, and Lawrence, "The world and the river," 2286.

108. Williams, ibid.

109. Lawrence, "The word and the river," 2286.

110. Martha Minow, "Forward: Justice engendered," Harvard Law Review 101 (1987): 10.

111. Williams, The Alchemy of Race and Rights, 216.

112. Marshall, "Citizenship and social class."

113. This is of course only an analytic distinction; no narrative can be purely symbolic or material.

114. Pierre Bourdieu, An Outline of a Theory of Practice; "Social space and the genesis of groups"; and "The habits and the space of life-styles," in Distinction: A Social Critique of the Judgement of Taste, trans. Richard Nice (Cambridge: Harvard University Press, 1986).

115. This is a situation described in detail in Margaret R. Somers, "Citizenship and the place of the public sphere: Law, community, and political culture in the transition to democracy," American Sociological Review 58 (1993): 587-620. 
116. Somers, "Property, law, and the public sphere."

117. See F. M. L. Thompson, "Social control in Victorian Britain," Economic History Review, 2nd Series 34/2 (1981): 189-208, and Alistair Reid, "Politics and economics in the formation of the British working class: A response to H. F. Moorhouse," Social History 3/3 (1978): 347-361, for a sense of how pervasive the social control thesis was in social history during the $1970 \mathrm{~s}$.

118. Michael Sandel, Liberalism and the Limits to Justice (Cambridge: Cambridge University Press, 1982), 178. See also Robert Bellah, Habits of the Heart (Berkeley: University of California Press, 1985).

119. See Maurice Halbwachs, The Collective Memory (New York: Harper \& Row, 1980 (1950)); Scott, Gender and the Politics of History; and Benhabib, Situating the Self.

120. E.g., Chodorow, The Reproduction of Mothering; Gilligan, In a Different Voice.

121. JoEllen Shively, "Perceptions of western films among American Indians and Anglos," American Sociological Review 57 (1992): 725-734.

122. The question of the epistemological place of categories in the context of an overall relational and narrative approach is a major theme of White's Identity and Control. Calhoun, in "Imagined communities," discusses categoties and relationships by bringing White's "structural equivalence" and "indirect relationships" to the study of nationalism and identity.

123. Steven Brint, "Hidden meanings: Cultural content and context in Harrison White's structural sociology," Sociological Theory 10/2 (1992): 194-207, 196. And see White's response to this criticism of what Brint sees as an overly relational approach to sociology, in Harrison C. White, "A social grammar for culture: Reply to Steven Brint," Sociological Theory 10/2 (1992): 209-213. 